\title{
Contextualising archaeological models with geological, airborne and terrestrial LiDAR data: the Ice Age landscape in Farndon Fields, Nottinghamshire, UK
}

${ }^{a}$ British Geological Survey, Natural Environment Research Council, Nicker Hill, Keyworth, NG12 5GG, UK;

${ }^{\mathrm{b}}$ Beeston, Nottinghamshire

* Corresponding author. Telephone: +44 (0) 1159363537

3

E-mail address: deodato@bgs.ac.uk; deodato.tapete@gmail.com

DeODATO TAPETE $^{\text {a }}{ }^{*}$, VANESSA BANKS $^{\text {a }}$, LeE JONES $^{\text {a }}$, MATTHEW KIRKHAM $^{\text {a }}$, DARYL GARTON $^{\text {b }}$

\section{Abstract}

Archaeological models of past human occupation of the landscape build upon the understanding of the natural palaeo-environment. This cognitive process relies on the study of the sediment units at a level of spatial resolution that might not be achieved with available maps. This paper presents a new approach to combine traditional ground investigation methods and new technologies to detect, extract and analyse stratigraphic records, with particular application to vanishing landscapes with limited exposure of the sediments. The demonstration site is Farndon Fields, an extremely rare Late Upper Palaeolithic open-air site at the southern outskirts of Newark-on-Trent in Nottinghamshire, UK. Since the early 1990s when the upgrading of the new A46 road was planned, ground and archaeological investigations have been carried out. The test-pitting undertaken by Farndon Archaeological Research Investigations (FARI) in the field 373A in September 2015 offered an ideal occasion for the British Geological Survey (BGS) to test the methodology. A palaeo-geographic understanding from regional to local scales is here proposed based on 5-m airborne Light Detection and Ranging (LiDAR) data and multispectral aerial photographs of the site prior to the alteration due to the A46 works. Features of the palaeo-landscape are vanishing and intrusive investigations are required to unveil the presence of the archaeological context. Samples were taken for particle size analysis of the sediment units to characterise the aeolian sand deposits ('coversands') and the underlying clayey silty sandy sediments interbedded with paler laminae. For the first time state-of-the-art terrestrial LiDAR technology was 
22 used for stratigraphic profiling, strata delineation and geological feature extraction based on the 23 intensity return and surface roughness. The combined use of point clouds, 3D models and cloud 24 intensity from terrestrial LiDAR provides an added level of confidence to the ability to subdivide the 25 sediment units and discriminate them from ploughsoil. Internal bedding of the coversands is enhanced 26 in the LiDAR elaborations. This is new evidence not otherwise observed by the naked eye. On the 27 other side, the classification of point clouds by roughness index seems promising for recording the 28 grading of the sediments. The experiment in Farndon Fields therefore demonstrates the benefit of

29 phased technology-based investigation combining archaeology and geology towards a more cost30 effective assessment through strategic sampling and digital recording of landscape domains.

\section{KEYWORDS}

32 Anthropogenic deposits; palaeo-environment; coversands; geological mapping; LiDAR; terrestrial 33 laser scanner; Farndon Fields 


\section{INTRODUCTION}

'Geoarchaeology' is an established sub-discipline of archaeology which promotes the application of earth-science approaches to archaeological interpretation (Rapp and Hill, 2006) to study soils, palaeosoils, anthrosoils and sediment units of archaeological sites and cultural landscapes. Test-pits and trench excavation are the traditional intrusive methods used to corroborate hypotheses of archaeological potential, understand the processes that formed and protected an archaeological site (Schiffer, 1987) and investigate palimpsests (Bailey, 2007).

However, discrimination of archaeological horizons from and throughout geological strata is still a challenging task (see Edgeworth et al., 2015 for the recent debate in the Anthropocene research field). Through time sediment units may have been altered by biological processes, roots and ploughing. Once exposed to open air, they also may oxidise or be washed out if not properly sheltered during the archaeological survey. Even in good visibility conditions, cost-effective means for objective documentation are required to: record the exposed features more quickly; allow digital accessibility to the stratigraphy when test-pits and trenches are closed; collect spatial information over wide surfaces; optimise the selection of the points from which samples are taken and then investigated in the lab.

Emerging technologies of geological mapping and documentation, such as Light Detection and Ranging (LiDAR), are therefore helpful and allow digital storage of information. Recent literature (Challis, 2005; 2006; Malone, 2012) demonstrate that LiDAR data taken from aircrafts can be valuable for discoveries of geoarchaeological resources in alluvial environments. Nevertheless, limits can be found at the landscape scale for the identification of spatial patterns and discrimination of differential preservation potential (Challis et al., 2011).

At another scale, techniques for digital data capture using ground-based instrumentation - namely close-range photogrammetry, terrestrial laser or structured light scanners - can be more suitable for archaeological fieldwork. Lerma et al. (2014) recorded exposed surfaces and manmade artefacts; Sanger (2005) analysed depositional events; Doneus and Neubauer (2005, 2006) documented temporary layers and units of stratification during the progress of stratigraphic excavations; Fisher et 
al. (2015) created a full digital record of the archaeological survey and visualised results of laboratory analyses in the correct sampling locations along the stratigraphic columns. These examples prove that digital technologies are increasingly integrated in the cognitive and analytical process of archaeological excavations.

In this context, our paper aims to explore the process by which LiDAR data taken with airborne and terrestrial instrumentation can support a geoarchaeological study to upscale regional geological data, complement profiling of archaeological stratigraphy and characterise sediment units.

We provide a demonstration through the results obtained in the Late Upper Palaeolithic (LUP) open-air site at Farndon Fields, Nottinghamshire (UK). This is a nationally important site which may preserve the most significant geoarchaeological resource in the country referring to the intermittent revisits of the hunter community that first colonised Britain after the Last Glacial Maximum (Jacobi and Higham, 2009; English Heritage, 2012; Highways Agency, 2012).

Section 2 provides an introduction to Farndon Fields, its geological setting and archaeological resources. Section 3 describes the methodological approach of in-situ ground investigations and laboratory analyses. Section 4 presents the research outcomes in a multi-scale perspective, from regional to local scales. Section 5 outlines the significance of the geological evidence collected in September 2015 through LiDAR to frame and contextualise the archaeological model of human occupation of Farndon in LUP. Section 6 summarises the long-term benefits of digital recording of temporary excavations and outlines future directions of research.

\section{FARNDON FIELDS}

'Farndon Fields' is the toponym of our study area located in the flattish interfluve on the Holme Pierrepont Terrace of the River Trent (centre coordinates: WGS84 $53.059229^{\circ} \mathrm{N} ; 0.839340^{\circ} \mathrm{W}$; OS Grid Reference SK 77883 51960; 477883.776,351960.501), less than 2 km south-west of where the tributary River Devon joins the River Trent at Newark (Figure 1). The site is presently privately- 
owned cropland and, with permission, can be accessed from Fosse Way. This road passes through the modern village of Farndon following the former course of the namesake Roman road.

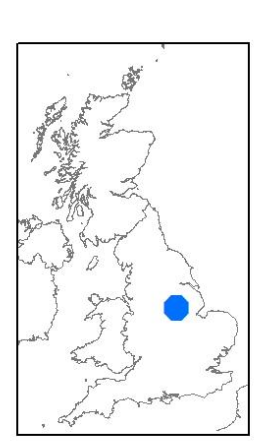

(a)

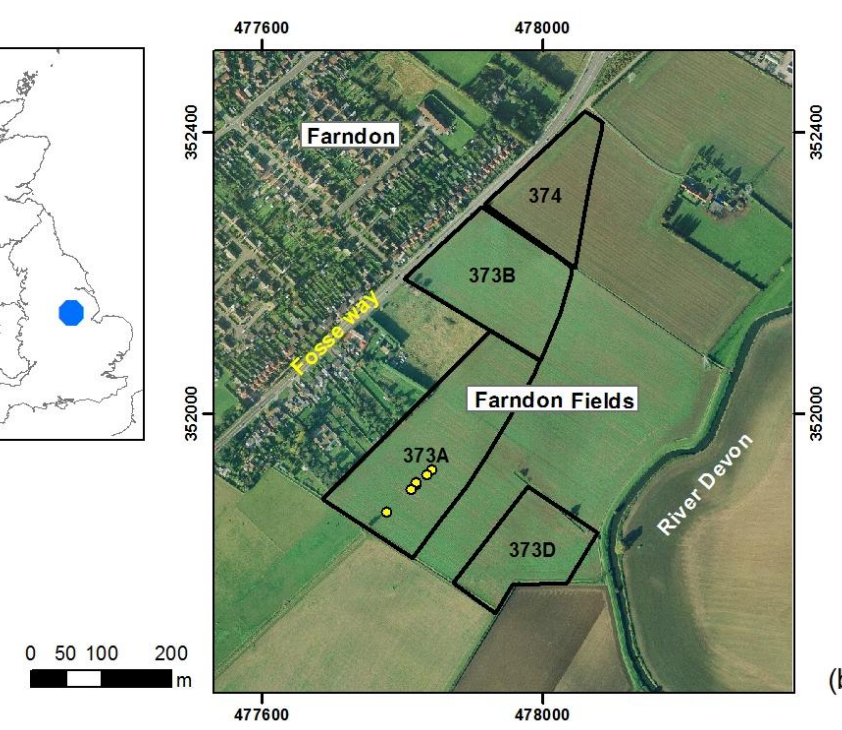

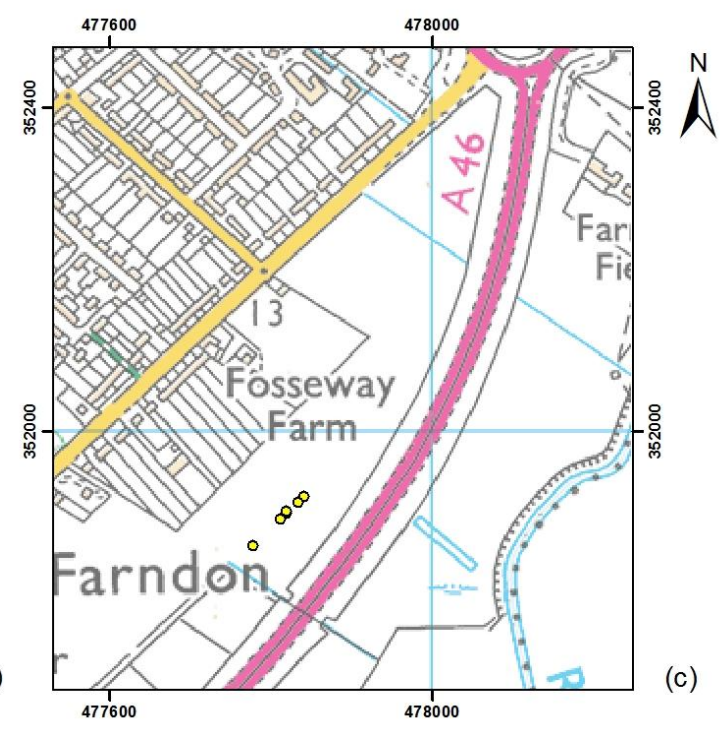

Figure 1 - Farndon Fields, south of Newark-on-Trent, Nottinghamshire, England, UK: (a) location map; (b) aerial view of the site prior to the construction of A46 road, with indications of the fields surveyed by Farndon Archaeological Research Investigations (FARI); (c) Ordnance Survey (OS) topographic map at 1:25,000 scale including the route of the A46 and the Farndon roundabout. Yellow dots in (b) and (c) indicate the station points from which the test-pits (TP) dug out by FARI during the archaeological survey in 2015 were scanned by the British Geological Survey (BGS) with terrestrial laser scanner (TLS). British National Grid; Projection: Transverse Mercator; Datum: Ordnance Survey Great Britain (OSGB) 1936. Contains OS data (C) Crown Copyright and database rights 2016. Aerial photography @ C UKP/Getmapping Licence No. UKP2006/01.

\subsection{Geological setting}

The geological setting is summarised in Table 1 and displayed in the geological maps of the superficial deposits and bedrock geology in Figure 2. The geological information come from: the Mineral Assessment Report by Price and Rogers (1978); mineral assessment surveys undertaken by the Institute of Geological Sciences (now the British Geological Survey - BGS) during the 1970s and 1930s; the current 1:50,000 scale map (E126; BGS, 1996); the digital equivalent at 1:50,000 and 1:10,000 scales (BGS, 2016a); and the sheet memoir (Howard et al., 2009). The geological terminology used in Figure 2 and in this paragraph follows the BGS Lexicon of Named Rock Units 
(BGS, 2017). The recent geological research on the terraces of the River Trent (Bridgland et al., 2014) has been taken into account.

The site is underlain by bedrock comprising the Edwalton Member of the Sidmouth Mudstone Formation. This is capped by the Holme Pierrepont Sand and Gravel Member of the Trent Valley Formation. The Balderton Sand and Gravel Member (Brandon and Sumbler, 1991) caps the higher terrace to the east and ribbons of Alluvium occupy the flood plains of the Rivers Trent and Devon. Holocene and Devensian Head deposits, including colluvium, are particularly associated with the edges of the terraces. The 1:10,000 mapping recorded on the field slip indicates that the surface expression of the Holocene Alluvium evident in the area of field 373D (i.e. in the field located southeast of the area investigated in 2015; Figure 1b) comprises "brown and ochre clays" at surface, whilst the Holme Pierrepont Member is characterised by "brown loamy sand with abundant gravel (of Bunter and flint)". The term "Bunter" is a reference to pebbles that are derived from the Sherwood Sandstone Group that outcrops in the order of $14 \mathrm{~km}$ to the west of Farndon. These are well rounded pebbles, predominantly of quartzite. Logging of ditch sections indicates that the near surface strata were underlain by gravels at about $1.7 \mathrm{~m}$ depth. The superficial deposits named "Head" blanket the gentle slopes on the inside of the meander on the eastern side of the River Devon (Figure 2a).

Further to the BGS mapping more detailed environmental analysis of the Holme Pierrepont Sand and Gravel Member has been undertaken through the Aggregates Levy Sustainability Fund (Howard et al., 2011). This research confirmed the cool climatic conditions of deposition of the Holme Pierrepont terrace deposits, suggesting that it was laid down in two pulses, immediately prior to and post the Loch Lomond stadial (Younger Dryas Marine Isotope Stage (MIS) 1). 
Table 1 - Geological succession of Farndon Fields, Nottinghamshire (lithology based on Howard et al., 2009).

\begin{tabular}{|c|c|c|c|}
\hline $\begin{array}{l}\text { Group/ } \\
\text { Subgroup }\end{array}$ & Formation & Member & Lithology \\
\hline \multirow[t]{3}{*}{$\begin{array}{l}\text { Trent-Witham } \\
\text { Catchment }\end{array}$} & \multirow[t]{3}{*}{ Trent Valley } & Hemington & $\begin{array}{l}\text { Holocene Alluvium associated with the modern } \\
\text { rivers (Trent and Devon). }\end{array}$ \\
\hline & & Holme Pierrepont & $\begin{array}{l}\text { Late Devensian, predominantly cold-phase } \\
\text { sands and gravels that underlie the Holme } \\
\text { Pierrepont Terrace. The Holme Pierrepont Sand } \\
\text { and Gravel Member includes the Spalford Sand } \\
\text { (type area: Spalford [SK } 840 \quad 690] \text {, } \\
\text { Nottinghamshire). The Spalford Sand comprises } \\
\text { spreads of pale brown, fine grained blown sand, } \\
\text { up to about } 3 \mathrm{~m} \text { thick, overlying the sand and } \\
\text { gravel. It is thought to be Late Devensian (MIS } \\
\text { 2), possibly Late Glacial in age (Brandon and } \\
\text { Sumbler, 1988). }\end{array}$ \\
\hline & & $\begin{array}{l}\text { Balderton Sand and } \\
\text { Gravel (Older } \\
\text { Gravel) }\end{array}$ & $\begin{array}{l}\text { Predominantly cold phase sands and gravels that } \\
\text { underlie the Balderton Terrace; includes aeolian } \\
\text { coversands and periglacial deposits. }\end{array}$ \\
\hline \multirow[t]{3}{*}{ Penarth } & \multirow[t]{3}{*}{$\begin{array}{l}\text { Sidmouth } \\
\text { Mudstone } \\
\text { Formation }\end{array}$} & Edwalton Member & $\begin{array}{l}\text { Red-brown and greenish grey Triassic } \\
\text { mudstones and siltstones, with beds of siltstone } \\
\text { and very fine-grained sandstone common in the } \\
\text { lower half; finely disseminated gypsum } \\
\text { common in upper half. }\end{array}$ \\
\hline & & Cotgrave Member & $\begin{array}{l}\text { Triassic pale greenish grey fine- to medium- } \\
\text { grained sandstone, interbedded with dark } \\
\text { greenish-grey mudstone and siltstone. Gypsum } \\
\text { nodules occur throughout. }\end{array}$ \\
\hline & & Gunthorpe Member & $\begin{array}{l}\text { Red-brown mudstone, with subordinate greenish } \\
\text { grey siltstone and fine-grained sandstone and } \\
\text { common gypsum veins and nodules. }\end{array}$ \\
\hline
\end{tabular}




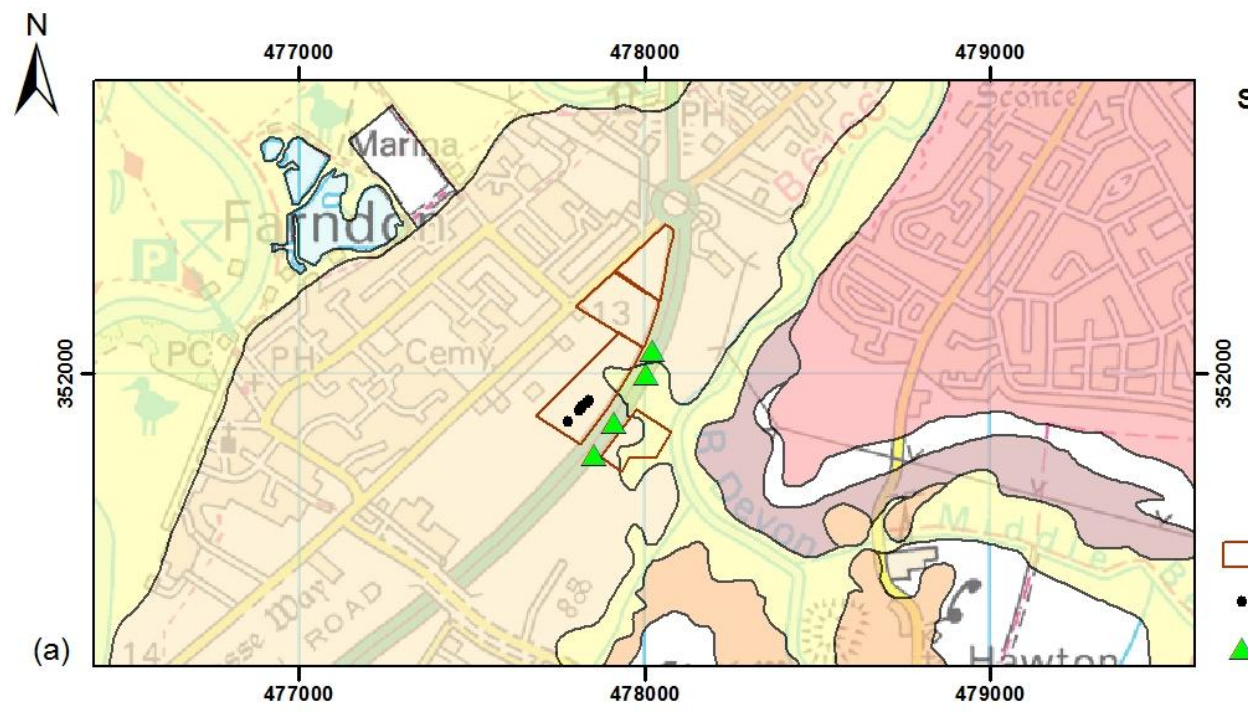

Superficial deposits $1: 10,000$

$\square$ Holocene Alluvium
$\square$ Holme Pierrepont Sand and Gravel Member

$\square$ Head

:

River Terrace deposits (undifferentiated)

Balderton Sand and Gravel Member

$\square$ no deposits mapped

$\square$ fields investigated 2012-2015

- test-pits (archaeological survey 2015)

$\Delta$ closest boreholes from BGS collection

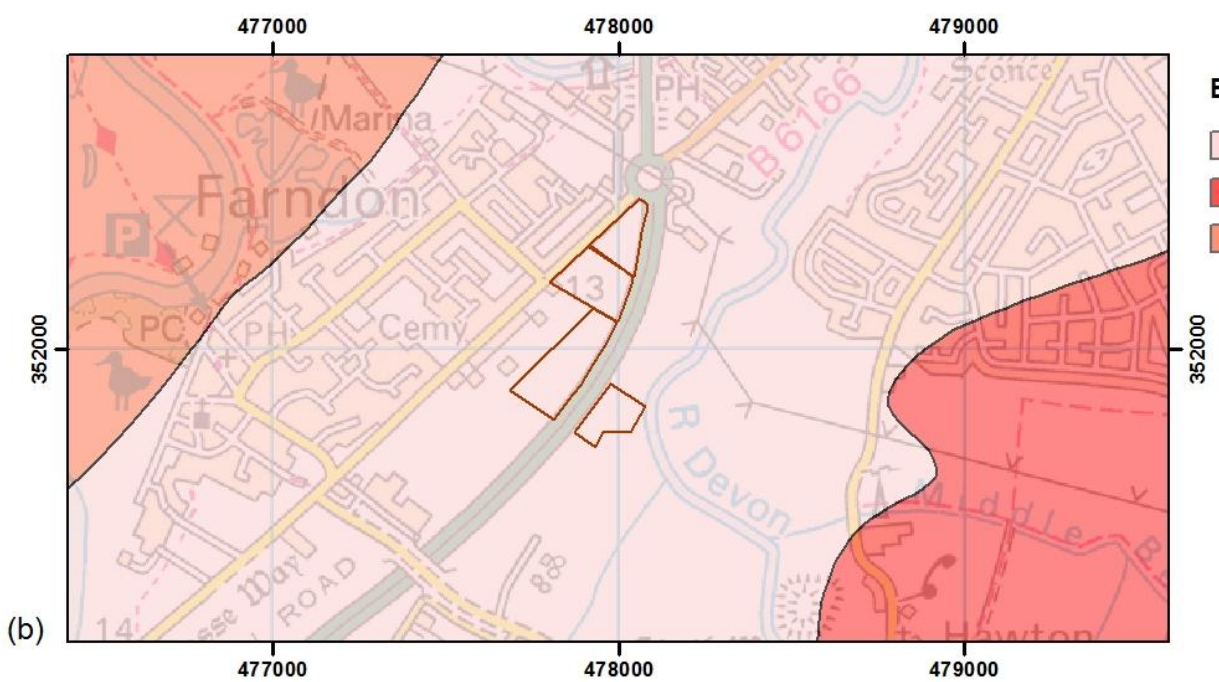

Bedrock geology 1:10,000

Edwalton Member

Branscombe Mudstone Formation

Gunthorpe Member

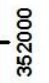

131 Figure 2 - Geological maps of (a) superficial deposits and (b) bedrock geology based on BGS' Digital 132 Geological Map of Great Britain (DiGMapGB) at 1:10,000 scale (BGS, 2016a), with location of the boreholes 133 closest to the field 373A (see also Figure 1 and Figure 3) that were drilled for the A46 Newark to Widmerpool 134 improvements and can be consulted via BGS' Geology of Britain Viewer (BGS, 2016b). British National Grid; 135 Projection: Transverse Mercator; Datum: OSGB 1936. Geological materials () Natural Environment Research 136 Council (NERC). All rights reserved 2016. Contains OS data ( $)$ Crown Copyright and database rights 2016. 


\subsection{Archaeological resources}

142 The archaeological potential of alluvial deposits and geomorphological settings across the Trent Valley has been investigated and modelled by Brown et al. (2005, 2007) and Howard et al. (2008). This research proved how river confluence zones and their adjacent floodplains could be ideal sites for hunter communities. In particular, by incorporating within the GIS archaeological records, BGS geological data at 1:50,000 mapping scale and airborne LiDAR, Howard et al. (2008) found that at the confluence zone of the Rivers Trent and Soar, north of Kegworth, the Holme Pierrepont Sand and Gravel "represents a stable land surface of considerable antiquity and offers the potential to preserve multi-period archaeological remains (i.e. Upper Palaeolithic to post-medieval)”.

The archaeological importance of Farndon Fields was proved in 1991, when the proposed construction of the new A46 road - which currently runs diagonally across the site (Figure 1c) - was initiated by the Highways Agency. This infrastructure work triggered the planning context for a series of systematic fieldwalking campaigns and site investigations (Garton, 1993; Garton and Jacobi, 2009; Highways Agency, 2012; Kinsley and Knight, 1992; Wessex Archaeology, 1995; and for a review of past and recent fieldwork in Farndon see Garton et al., 2015). This research allowed the discovery of significant in-situ concentrations of flintwork and microdebitage attributed to two distinctive Creswellian and Federmesser LUP blade technologies (c. 14,700 to c. 12,900 cal BP; Highways Agency, 2012; Harding et al., 2014). The findings stimulated the speculation whether these flint scatters might testify that Farndon Fields was a temporary settlement of hunter-gatherer bands ranging between the Trent Valley and the cave sites of the Magnesian Limestone escarpment (Knight, 2004;

161 Knight et al., 2012) and seeking the fresh water available at this site (Highways Agency, 2012). Farndon Fields was further investigated since 2012 by the voluntary group 'Ice Age Journeys', with the aim to determine the state of preservation of the sediment units outside the road-line. Both northern (ID 374, 373B) and southern (ID 373A, 373D) fields (Figure 1b) were studied using a combination of

165 fieldwalking, augering and test-pitting. The findings have been recently presented and discussed by 166 Garton et al. (2015). 
A key discovery of this report is the evidence that previously undisturbed LUP clusters and scatters

168 have begun to be severely damaged by recent ploughing. This process has been observed in particular in the southern fields, in locations that are close to relatively thick alluvium and wind-blown sand deposits (called 'coversand'), where Garton et al. (2015) hypothesised that more complete Late Glacial sequences might be better preserved.

It is worth recalling that the East Midlands are also one of the few regions in Britain where there is evidence of Late Pleistocene 'coversands'. This term indicates periglacial, aeolian sand deposits consisting of moderate to well-rounded spherical, well-sorted sand particles (mean grain size of about 150-200 $\mu \mathrm{m}$ ), lacking interstitial silt and clay, with a low percentage of the fraction finer than $63 \mu \mathrm{m}$. Layering is largely horizontal or sub-horizontal (Baker et al., 2013). Generally, coversands manifest as a relatively flat and thin mantle $(<5 \mathrm{~m})$ over older sediments, extending from a few to thousands of square kilometres (Bateman, 1995, 1998). Contrasting with the European geological stratigraphies, British coversand deposits tend to be limited in extent and fragmented (Baker et al., 2013). Dating evidence suggests that a number of periods of deposition are represented in Britain. In Lincolnshire, thermoluminescence dating by Bateman (1995) suggests contemporaneity with the Younger Coversand II in the European coversand chronology (Koster, 1988). There remains uncertainty about the processes of coversand deposition, local fluvial and niveo-aeolian deposition and reworking may have supplemented the initial wind transportation of sediments derived from open and bare surfaces during cold periods (Bateman, 1995 and references therein; Garton et al., 2015). environmental change during the Late Pleistocene and early Holocene. Coversands at Farndon occur as outliers of limited extent, filling palaeo-hollows in the valley floodplain. They are the most southerly remnants of a coversand sheet extending into this eastern region of Great Britain. Lower Trent coversands formally belong to the Spalford Sand Member of the Trent Valley Formation (Brandon and

191 Sumbler, 1988), the depositional environment of which is described in Baker et al. (2013) and Howard et al. (2007). 
An additional layer of data has come from the trial pits excavated for the A46 road improvement

194 scheme, comprising archaeological resource and mitigation (associated with the geotechnical survey of the proposed route) investigations (Wessex Archaeology, 1995, 2006). This work provided more detail on the near surface soils distinguished into (Wessex Archaeology, 2006):

- "the topsoil (ploughsoil) typically comprised dark greyish brown [...] non-calcareous heavy clay loam, and generally 0.3-0.35 m across the Site [Farndon Fields]”;

- "the subsoil, varying in thickness between $0.2 \mathrm{~m}$ and $0.9 \mathrm{~m}$, was recorded in all trial pits [...] either very sandy clay or clayey sand of variable colours, although generally yellowish brown”.

The upper levels of the "subsoil" were noted to have been disturbed by bioturbation and cryoturbation processes. According to Harding et al. (2014), "variations in the subsoil (including several clearly defined units)" could be taken as "indicative of episodic pre-Holocene alluviation and/or solifluction, which could have preserved surfaces and/or horizons containing LUP material below the present ploughsoil (TPAU, 2004)".

Whilst the association of the Late Upper Palaeolithic activity (14,700 to 12,900 BP) with the Holme Pierrepont Terrace in Farndon was established through fieldwalking (Garton, 1993; Wessex Archaeology, 1995, 2006; Knight and Howard, 2004), the subsequent intrusive archaeological investigations identified: (i) the difficulty that there has been in establishing in-situ subsurface buried landscape of occupation terraces; (ii) the in-situ nature of the archaeological finds, largely unaffected by the periglacial activity evident in the in-situ strata, and (iii) the impact of the plough depth on the archaeological resource (Harding et al., 2014; Garton et al., 2015).

All the above highlights the archaeological importance of these wind-blown and fluvial sediment units, as well as the challenge faced by archaeologists in Farndon to establish a method for their 215 interpretation as clearly defined units. These sediment units were therefore the subject of the laboratory analyses (sections 3.2 and 4.3) and LiDAR experiment (sections 3.4 and 4.4) of this research. 


\section{MATERIALS AND METHODS}

\subsection{Test-pitting}

Figure 3a shows a zoomed aerial view of Farndon Fields, with the location of the archaeological cross-section A-A' investigated by Farndon Archaeological Research Investigations (FARI) in September 2015 by test-pitting the Field 373A. This area of Farndon Fields is located south of the excavations made by FARI in 2014 and had been investigated in 2013 by systematic fieldwalking, where the distribution of artefacts on the surface of the ploughed field had been recorded (Garton et al., 2015), and by a dedicated hand-augering survey using a dutch-head in January 2015 (unpublished report for Ice Age Journeys by William G. Mills, PhD student at the University of Oxford). This augering identified a sand deposit, provisionally interpreted as coversands, thickest in the area where fieldwalking had not located LUP artefacts. Nick Barton (University of Oxford) had raised the possibility that coversands might have buried LUP activity and artefacts might still lie below the reach of modern agriculture, so they would not be found by fieldwalking the ploughed field-surface. Hence a series of test-pits (TP) was located to sample the deepest sediment units and across the feather-edge of the potential coversand as it thinned to the north.

TP were opened by hand (using trowels, small hand-mattocks and spades) in spits (maximum depth $0.10 \mathrm{~m}$ ) and a nominal size of $1 \times 1 \mathrm{~m}$ to reach the sediment units at the bottom and expose the stratigraphic sequence. Western or northern inner pit-sections were documented and OS coordinates were taken at the ground level and key stratigraphic horizons.

To refer to the sediment units observed in the TP, hereinafter we use the following terms, from top to bottom: ploughsoil, coversands, fluvial deposits, gravel terrace. When the fluvial deposits are distinctively interbebbed with laminae, they are referred to as "laminated sediments" (see also section 4.2). 

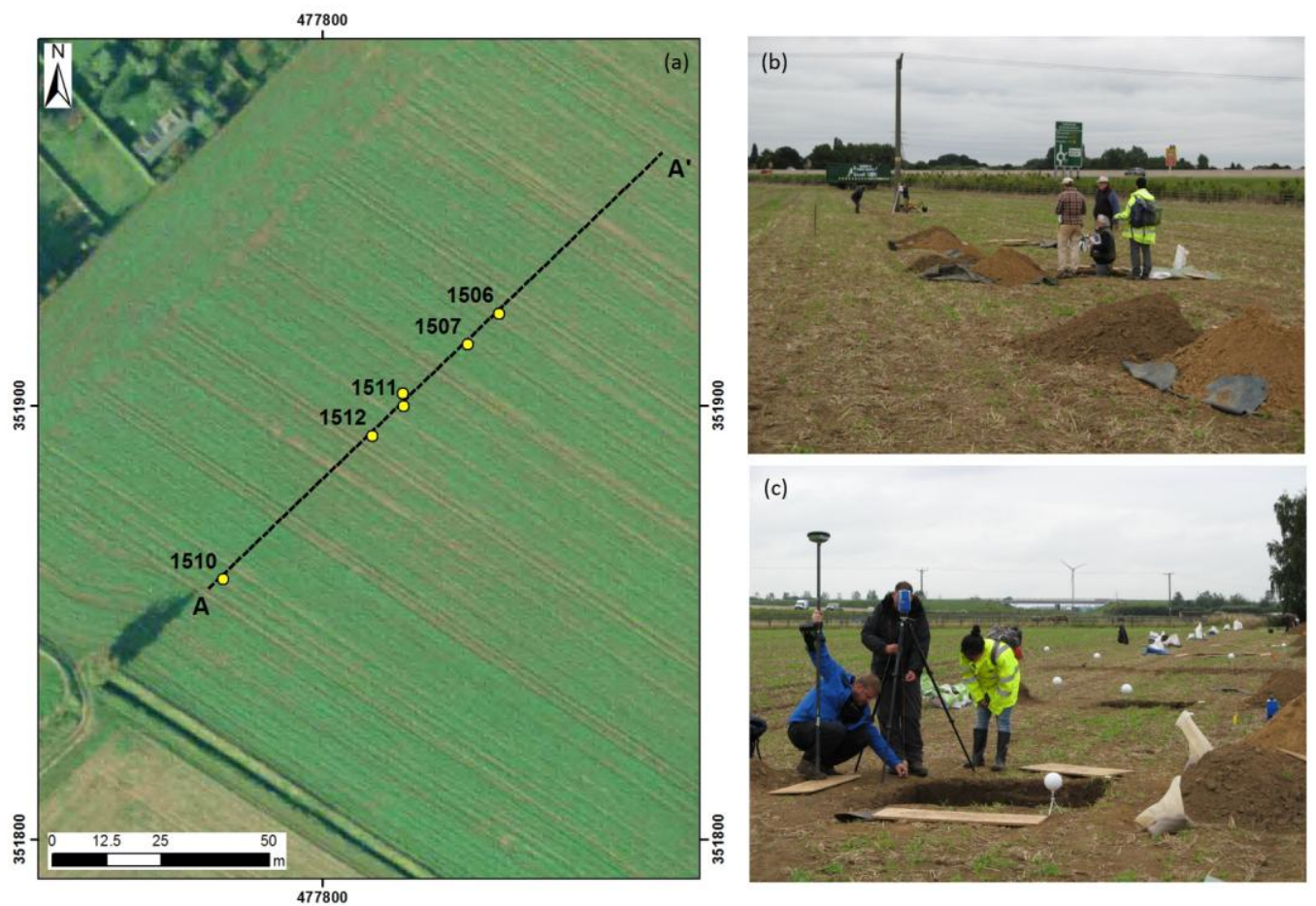

243 Figure 3-Zoomed view of Farndon Fields, with location of: the archaeological cross-section A-A' investigated 244 during the test-pitting undertaken in September 2015; and the terrestrial laser scanner stations (yellow dots) 245 from which five of the test-pits (TP1510, 1512, 1511, 1507, 1506) were scanned. (C NERC. All rights reserved) 246 (b) View of the TP and the proximity to the A46 road. (c) Terrestrial laser scanning acquisition of one of the TP 247 (photo credit: Daryl Garton). British National Grid; Projection: Transverse Mercator; Datum: OSGB 1936. 248 Aerial photography (C) UKP/Getmapping Licence No. UKP2006/01.

\subsection{Sediment sampling and Particle Size Analysis (PSA)}

251 Table 2 shows the list of bulk sediment samples that were collected through the stratigraphy within the 252 TP. Location of the five TP is showed in Figure 3a. Particular attention was given to sample within the 253 selected sediment units, avoiding the ploughsoil. The samples were then stored within water-proofed 254 and sealed bags to preserve the moisture content. 
Table 2 - Sediment samples collected from the TP in Farndon Fields during the archaeological survey in 2015 258 (for TP location and sample stratigraphic position see Figure 3a and Figure 6, respectively). Depth is measured 259 from the ground surface; OS elevations are provided.

\begin{tabular}{|c|c|c|c|c|c|}
\hline Test-pit & Section & Sample & Depth [cm] & $\begin{array}{l}\text { OS elevation } \\
\text { [m OD] }\end{array}$ & Description \\
\hline \multirow{5}{*}{1512} & Western & 1 & $94-101$ & $11.32-11.39$ & $\begin{array}{l}\text { Fluvial material only, below } \\
\text { coversand and lying above the } \\
\text { gravel terrace }\end{array}$ \\
\hline & Western & 2 & $85-92$ & top at 11.47 & Transition to the coversand \\
\hline & Western & 3 & $75-82$ & $11.51-11.58$ & Coversand \\
\hline & Western & 4 & $65-73$ & 11.63 & Coversand \\
\hline & Western & 5 & $53-63$ & $11.46-11.56$ & Coversand \\
\hline \multirow{4}{*}{1510} & Western & 6 & $83-90$ & $11.56-11.63$ & $\begin{array}{l}\text { Fluvial material only, below } \\
\text { coversand and lying above the } \\
\text { gravel terrace }\end{array}$ \\
\hline & Western & 7 & $74-81$ & $11.65-11.72$ & Transition to the coversand \\
\hline & Western & 8 & $64-71$ & $11.75-11.82$ & Coversand \\
\hline & Western & 9 & $54-61$ & $11.85-11.92$ & Coversand \\
\hline 1511 & Northern & 10 & $93-102$ & 11.27 & $\begin{array}{l}\text { Fluvial deposits, thicker upper } \\
\text { reddish portion }\end{array}$ \\
\hline 1507 & Western & 11 & $83-94$ & $11.09-11.20$ & Coversand (?) \\
\hline
\end{tabular}

Samples were taken from the western cross-sections of the TP, except for sample \#10 from the northern face of TP1511. In TP1510 and 1512 the sediments were sampled sequentially, with a regular spacing (every $10 \mathrm{~cm}$ ) moving up along the stratigraphy from the bottom fluvial sediments to the top coversands. Based on the field evidence (see section 4.2), we decided to recover two parallel sets of sediment samples, so we could achieve a good representation of the whole thickness of the coversands, including the transition with the underlying fluvial sediments. This type of sampling was meant to 
highlight potential differences in grain size distribution by means of Particle Size Analysis (PSA). This choice was justified in light of two considerations. The coversands are likely to be the result of a sequence of depositional phases, associated to different environmental and energy conditions. Furthermore, given the relative stratigraphic position of TP1510 and TP1512 (see Figure 6), a parallel sediment sampling could provide evidence of stratigraphic correlations between these two TP, thereby helping to understand the overall stratigraphic and geological profiles (see section 4.2).

PSA were carried out using a combination of wet sieving technique for the coarser fraction (> $63 \mu \mathrm{m})$ of the samples, and X-Ray Sedigraph for the finer fraction. Wet sieving was run according to the British Standards Institution (BSI) procedure described in BS 1377:1975, Test 7(A). The sieve spacing used to analyse the coarse fraction retained on the $0.063 \mathrm{~mm}$ sieve was $1 \Phi$ to $8.0 \mathrm{~mm}(-3 \Phi)$ and then as required for larger particles. The total dry mass and each individual size fraction of each Particle Size Distribution (PSD) are weight to $0.01 \mathrm{~g}$ giving an overall error of around $0.1 \%$ for the PSD of the samples received. For the X-Ray Sedigraph analysis of the fine fraction, $5 \mathrm{~g}$, oven dried, sub-sample was selected from the $<63 \mu \mathrm{m}$ washings of the whole sample and mixed with a $0.05 \%$ solution of sodium hexametaphosphate to form a suspension. The suspension was analysed in the Xray Sedigraph, the results of which were then integrated with the coarse analysis. The X-ray Sedigraph system was calibrated with a garnet standard of known particle size distribution prior to testing to ensure accuracy of the results.

\subsection{Airborne LiDAR and Radar}

The topography of Farndon Fields is generally flat with gentle slopes towards the River Devon in the east, with slight hummocks and hollows having a maximum fall of some $1.2 \mathrm{~m}$. Garton et al. (2015) has recently presented the elaboration by Ian Ross of LiDAR data licensed from the Environment Agency, to highlight ground levels between 10.5 and $12.0 \mathrm{~m}$ OD. The present paper extends this analysis using NEXTMap® Britain Digital Terrain Model (DTM) up to 5-m resolution (NEXTMap® Britain (C) 2003, Intermap Technologies Inc., All rights reserved), alongside true-colour Red-GreenBlue (RGB) and Infrared (IR) aerial photographs taken in May 2007 (tiles SK7751, SK7752, SK7851 
and SK7852) and licensed to the BGS. These remote sensing datasets were useful to observe the condition of Farndon Fields prior to the alteration due to the construction of the A46. We also used these data to detect features of potential archaeological and palaeo-environmental interest, also in relation to what was known from the fieldnotes and memoirs available at the BGS and already recalled in section 2.1.

\subsection{Terrestrial LiDAR scanning (TLS) survey and texture extraction}

To upscale the geological mapping in Farndon Fields and record the exposed geology, terrestrial LiDAR scanning (TLS) was undertaken. The topography of the site at the time of the excavation was collected and the inner surfaces of the TP1506, 1507, 1510, 1511, 1512 were recorded. The LiDAR scanner used for this survey was a Faro Focus 3D X-330. This is a short-range scanner (up to $300 \mathrm{~m}$ ) with an accuracy of $\pm 2 \mathrm{~mm}$, a measurement rate of 997,000 measurements per second and an internal high-resolution digital camera which enabled coloured point-clouds to be captured. The relative distance, elevation angle and azimuthal angle between the LiDAR and the survey objects were measured semi-automatically during each scan and, once processed, a 3D surface model was generated. A series of locations around the site were chosen as either scan positions (5; see Figure 1a and Figure 3a) or target positions (12). These were surveyed using a Leica GS14 Global Navigation Satellite System (GNSS), a 120-channel receiver with an accuracy of up to $3 \mathrm{~mm}$. This method relies on the accurate positional control of the GNSS and the use of spherical prisms (Figure 3c), checkerboard targets and planar surfaces as markers by which to 'tie' the scans together. At least four of these markers need to be visible in every two adjacent scans, meaning that at least 8 markers were visible in each separate scan, i.e. four markers visible to both scans 1 and 2 and four markers visible to both scans 2 and 3 (scan 2 sees both sets of markers). The reader could refer to English Heritage (2010) for hands-on guidance on how this is done in the field.

The LIDAR data produced by the oriented laser scan and GNSS survey were processed to develop a Digital Surface Model (DSM) in Scene, Faro's acquisition and processing software. The raw data produced by the Scene software consisted of a point-cloud comprising 900 million $\mathrm{x}, \mathrm{y}, \mathrm{z}$ points. These 
data were oriented using the GNSS control positions and the markers. The output is an American Standard Code for Information Interchange (ASCII) file, made up of x, y, z, intensity and Red-GreenBlue (RGB) colour values. Therefore, each point of the cloud is attributed not only the relative $\mathrm{x}, \mathrm{y}$ and $\mathrm{z}$ position in the three-dimensional space, but also the intensity of the reflected signal. Intensity is the amount of signal that has been reflected by the object surface hit by the laser of the LiDAR instrumentation (for further information see English Heritage, 2011).

The scans were then imported into Maptek I-Site Studio, point cloud processing and modelling software. From these data the DSM was generated across the whole site. Highly-detailed coloured point clouds of each trial pit were inlaid into the DSM (see Figure 9).

For each of the scanned TP, three products have been generated:

(i) the cleaned and processed point cloud;

(ii) the 3D model of the rendered surfaces;

(iii) the cloud intensity.

The latter output allows visualisation of the scanned surfaces based on the measurements of the magnitude of the reflected signal. According to the physical principles of LiDAR backscattering (Pfeifer et al., 2007; Krooks et al., 2013), intensity is also a function of the incidence angle with which the LiDAR laser hits the object surface. Some authors claim that this is a minor component of the intensity when imaging natural surfaces (Burton and Wood, 2010). Nevertheless, it is worth noting that differences in incidence angle and the resulting intensity are also due to different dip and surface roughness (i.e. asperities and protrusions) of the features observed over the stratigraphic sections within the TP. Therefore, using this LiDAR information, features across the stratigraphic column can be better enhanced and differentiated. In agreement with Challis et al. (2011), the intensity is used here as a surface descriptor of the earth material properties, to complement with the observations and feature detection undertaken by using the corresponding point cloud and 3D model. Section 4.4 demonstrates the benefits of processed TLS scans for better delineation of 
geological features such as boundaries between contiguous strata, laminations, glacial and periglacial features, inhomogeneity in the grain size.

\section{Results}

\subsection{LiDAR-based palaeo-geographic understanding}

At the landscape scale the DTM of the River Trent region confirms the flattish morphological setting of the environment where Farndon Fields is situated (Figure 4a). Compared with the topography of the surrounding countryside, this area at the current confluence of the Rivers Trent and Devon should have offered an ideal corridor to hunter community in LUP. According to the reconstruction based on the BRITICE database (Clark et al., 2004) and the very recent multi-stage recession model by Fairburn and Bateman (2016), Farndon Fields was likely formerly located towards the southern margin of the Glacial Lake Humber.

A close up of the site area enhances the extent of the terraces and the edges of the Holme Pierrepont Sand and Gravel Member which enclose Farndon Fields (Figure 4Figure 4b). At the northern end of the fields surveyed by FARI since 2012, the DTM shows a topographical high of about $13.4 \mathrm{~m}$ above OD. This is currently partially obscured by the junction of the A46 with the Farndon roundabout (feature B in Figure 4b). As the majority of the study area lies at lower elevation of about $12 \mathrm{~m}$ to $11.6 \mathrm{~m} \mathrm{OD}$, this topographic high is one of the most distinctive features that could have been observed before the A46 construction. Interestingly, the A46 embankment seems to have exploited this topographic high as a platform, alongside the other strip of higher elevation just south of the fields investigated in 2015 .

Another interesting feature that might relate to the palaeo-environment of Farndon is a curvilinear area of lower ground to the east of the A46 and field 373B (feature C in Figure 4b). Pending the results of targeted site investigation, it cannot be excluded that this pattern represents the remnant of a former meander loop of the River Devon. Additionally, as recently noted by Garton et al. (2015), old aerial photographs (e.g. Royal Air Force oblique image taken in April 1947, reference RAF_CPE_UK_2009_4418) and historic maps provide evidence of a former braided Holocene 
channel running towards the River Devon. These channels are not currently visible from above, even

371 in recent false-coloured IR images (Figure 5; see section 3.3 for the image reference). The only other 372 curvilinear feature that can be observed in this recent image is about $500 \mathrm{~m}$ SE of Farndon Fields. This 373 evidence would suggest that features, once more distinctive, are progressively vanishing as the 374 landscape is modified by contemporary human activities.
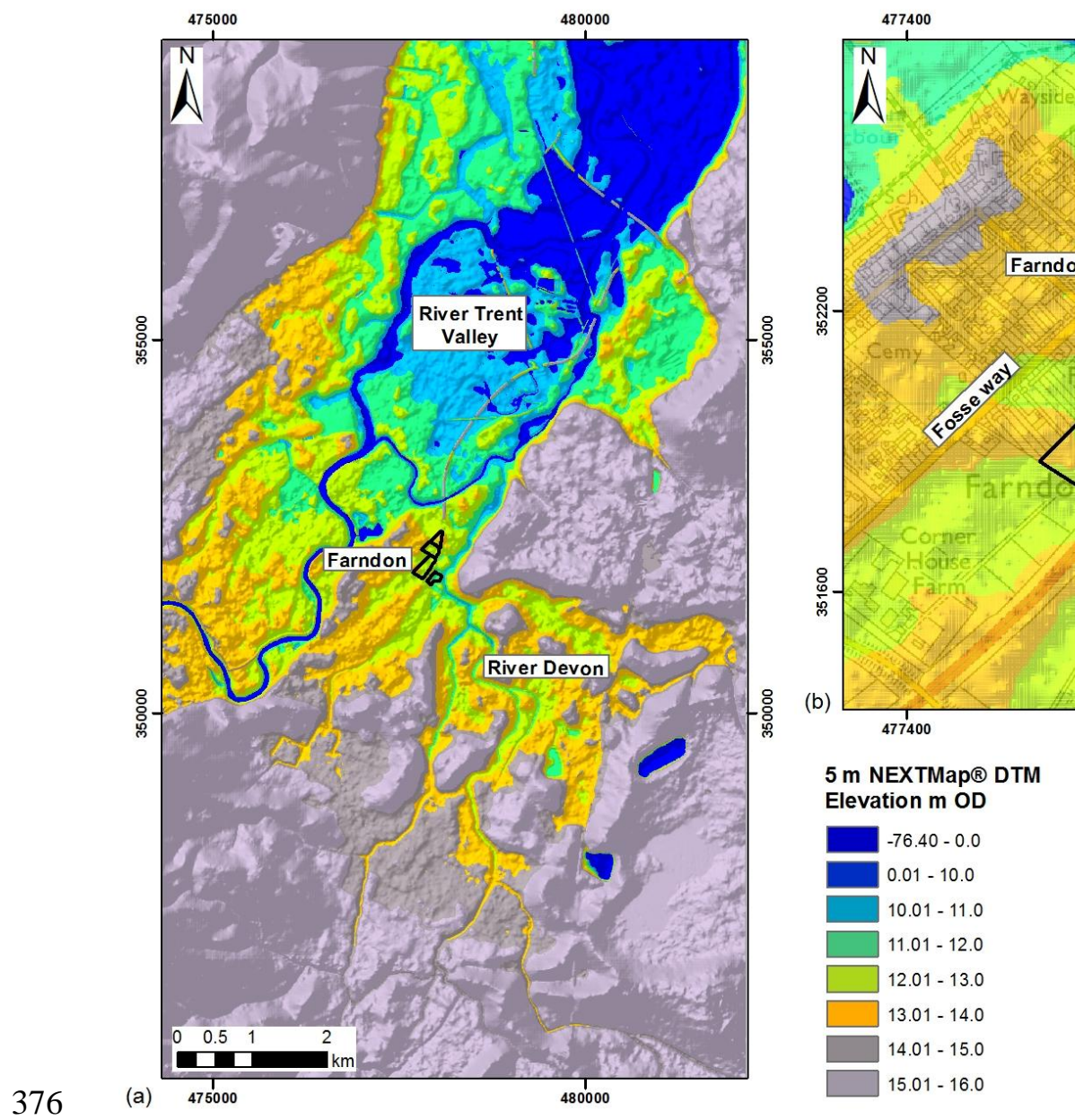
478000

Figure 4 - Digital Terrain Model (DTM) of (a) the Trent region around Newark and (b) Farndon Fields based on 5-m NEXTMap® DTM. British National Grid; Projection: Transverse Mercator; Datum: OSGB 1936. Vertical Datum: OSGM91. Contains OS data (C) Crown Copyright and database rights 2016. NEXTMap® 


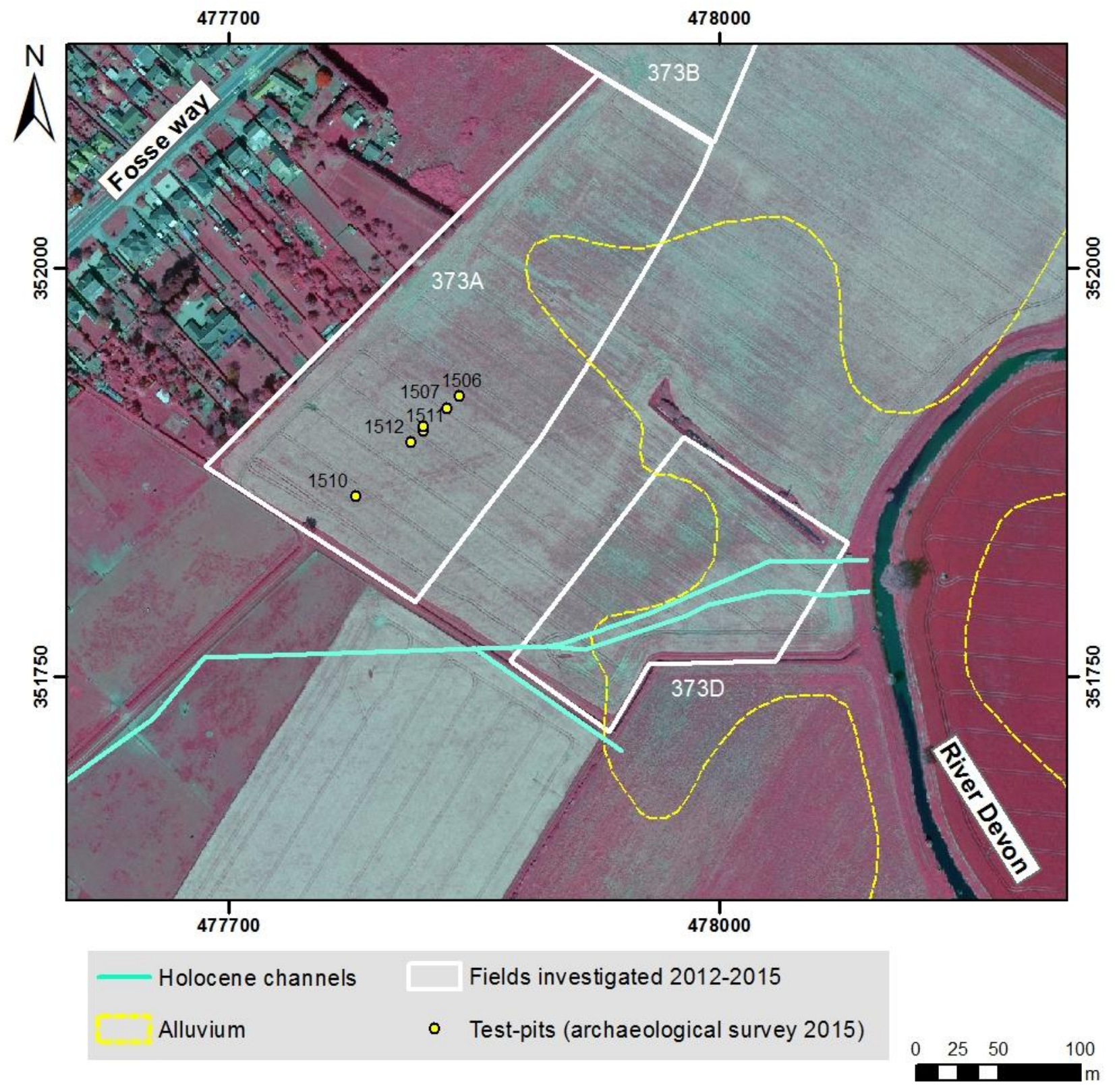

383 Figure 5 - False-coloured IR aerial photograph depicting the condition of Farndon Fields in May 2007 (photo 384 reference: PGA_SK7751_2007-05-01, licensed to BGS). The false-colour is obtained with the following 385 combination of the Red, Green and Blue (RGB) channels: near infrared light $=$ red channel $(\mathrm{R})$; red light $=$ 386 green channel $(\mathrm{G})$; green light = blue channel (B). The extent of the alluvium is derived from BGS' DiGMapGB 387 at 1:10,000 scale (BGS, 2016a; see also Figure 2a). The W-E track of the Holocene palaeochannel is drawn 388 based on old aerial photographs taken since 1933 (Garton et al., 2015, 109-110). Another palaeochannel 389 oriented NW-SE is drawn based on field data from Harding et al. (2014). British National Grid; Projection: 390 Transverse Mercator; Datum: OSGB 1936. Aerial photography @ UKP/Getmapping Licence No. UKP2006/01. 


\subsection{Stratigraphy}

393 Figure 6 shows the stratigraphy derived from in-situ observations and recording within the TP. At a 394 first glance, the most noticeable feature is the topographic gradient of the full stratigraphy of sediments 395 from SW to NE. This provides a stratigraphic confirmation of the surface topography measured from 396 the airborne LiDAR data (see Figure 4b).

397 Below the modern ploughsoil largely consisting of humus (Figure 7a-b and Figure 8a-b), all the TP show a thick body of sands - hereinafter referred to as coversands - varying in colour, from brownish shallower strata to pale yellow deeper sediments. Predictably, the highest strata are more bioturbated and affected by reworking due to repeated farming activities, although bioturbation affects most of the coversand body and constrains its visibility. The best and deepest exposure of the coversands is found over the western face of TP1512 (Figure 7a).

The dark brown clayey silty sandy sediments underlying the coversands are interbedded with paler laminae, more silty at touch and which are very distinctive, as shown in TP1510 (Figure 7b) and TP1511 (Figure 8a) - they are here referred to as "laminated sediments".

Between TP1513 and 1511 there is a step in the profile of the gravel terrace; the sediments are deepest around TP1511 and 1512. Pale polygonal cracking is visible in the terrace deposits at the base of TP1511; this might have been produced by freeze-thaw cycles of the ground. The cracks were subsequently infilled with fine sand. Vertical frost cracks run continuously from the sand and gravel deposits, through the laminated sediments and then into the overlying coversands (Figure 8a).

Pea-grit stringers are found within the laminae in most of the TP. During the survey, they were recorded at variable depths within the laminated deposits, sometimes forming distinct horizons which could be seen in section and sometimes visible only as sparse spreads whilst trowelling. In TP1511 the pea-grit is quite well sorted, thus suggesting a winnowed, higher energy flow event (see also LiDAR elaboration in Figure 17). In this regard, it is worth acknowledging that the environmental interpretation of the sediment units is ongoing and beyond the scope of this paper. 
15101516
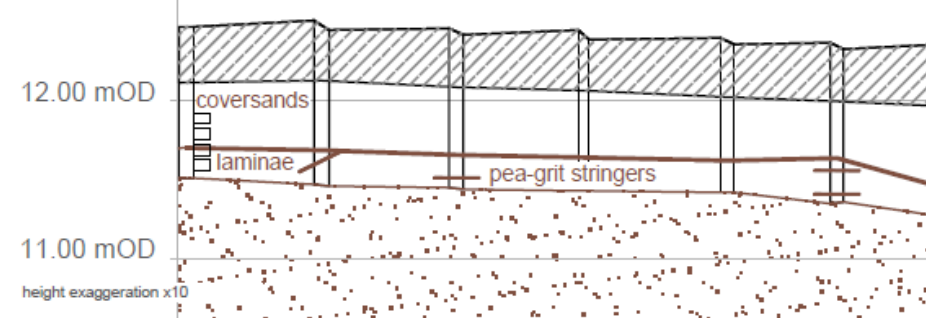

:

$\therefore$

and

f": " terrace sand

10.00 mOD SW :

420 Figure 6 - Stratigraphic profile of the test-pitting transect A-A' excavated and investigated in September 2015 (see location in Figure 3a), with position of the TP
1501

$1507 \quad 1506$

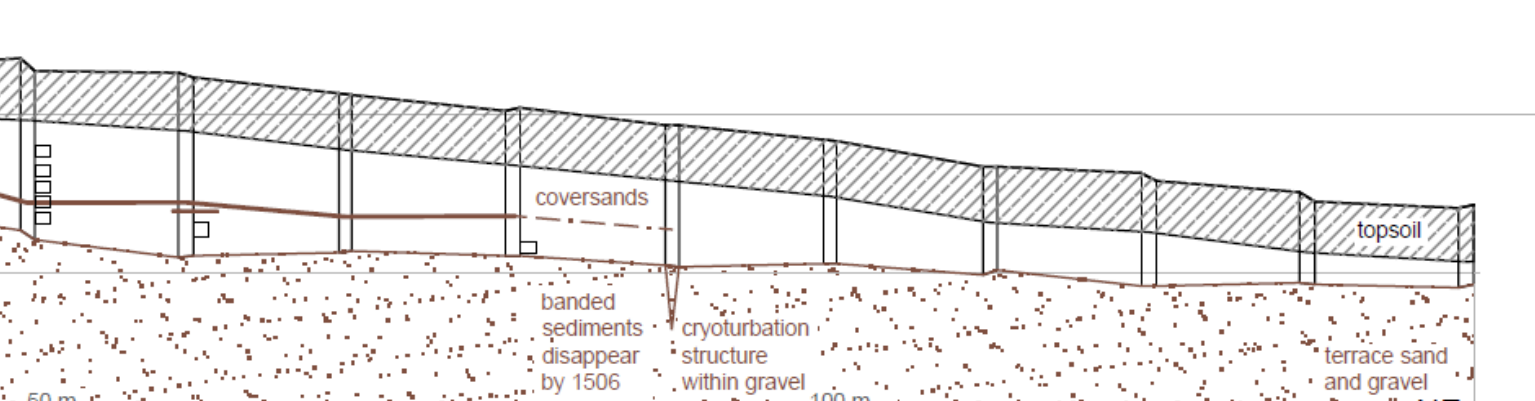




\subsection{PSA characterisation of the sediments}

423

Table 3 summarises the grain size properties of the sediment samples from Farndon Fields (see also Table 2), alongside their moisture content determined in drying oven. The respective grain size distribution curves are displayed in Figure 7 and Figure 8.

The two sequences sampled in parallel, in TP1510 and TP1512, show quite consistent PSA values. In both cases, the sediments are mostly poorly graded sands, with coarse fraction retained on the 63 $\mu \mathrm{m}$ sieve not less than $58 \%$. Higher percentages of finer fraction are found at deeper depths. The grain size distribution curves of samples \#1 and 2 in TP1512 and samples \#6 and 7 in TP1510 (see also Table 2) are characterised by a finer fraction tail (silt and clay; Figure 7c-d). A marked separation is then observed from sample \#2 to sample \#3 and from sample \#7 to \#8, when the clay fraction decreases markedly.

Calculations of the inclusive graphic skewness (Sk) for the coarser fraction according to the methods and nomenclature by Folk (1974) highlight that samples \#1, 2, 6 and 7 are all strongly negative skewed, with consistent Sk values close to -1.0. Similar figures are also retrieved for samples \#10 and 11 which are stratigraphically located within the laminated sediments (Figure 6 and Figure 8a-b) and both show fine fraction tails (Figure 8c).

As for the moisture content (Table 3), the highest value measured is about $13 \%$ and was found in sample \#6, i.e. located at the bottom of TP1510 and corresponding with the highest percentage of clay fraction $(22.5 \%)$, whilst the lowest moisture content (3.5\%) corresponded with the lowest percentage of the clay fraction $(5.0 \%)$ in sample \#3, towards the middle of the coversands. 
444 Table 3 - Summary of grain size properties of the samples from Farndon Fields (see also Table 2). Notation:

445 Maximum size of the smallest $10 \%\left(\mathrm{~d}_{10}\right), 30 \%\left(\mathrm{~d}_{30}\right)$ and $60 \%\left(\mathrm{~d}_{60}\right)$ of the sample; Coefficient of uniformity $\left(\mathrm{C}_{\mathrm{u}}\right)$,

446 Coefficient of curvature $\left(\mathrm{C}_{\mathrm{c}}\right)$.

447

Grain size properties

\begin{tabular}{ccccccccccc} 
Sample & $\begin{array}{c}\text { Gravel } \\
{[\%]}\end{array}$ & $\begin{array}{c}\text { Sand } \\
{[\%]}\end{array}$ & $\begin{array}{c}\text { Silt } \\
{[\%]}\end{array}$ & $\begin{array}{c}\text { Clay } \\
{[\%]}\end{array}$ & $\mathbf{D}_{10}$ & $\mathbf{D}_{30}$ & $\mathbf{D}_{60}$ & $\mathbf{C}_{\mathbf{u}}$ & $\mathbf{C}_{\mathbf{c}}$ & $\begin{array}{c}\text { Moisture } \\
\text { content [\%] }\end{array}$ \\
\hline 1 & 0.1 & 69.4 & 13.8 & 16.8 & - & 0.063 & 0.200 & - & - & 8.7 \\
\hline 2 & 0.2 & 78.3 & 11.5 & 10.0 & 0.002 & 0.100 & 0.250 & 125.00 & 20.00 & 5.7 \\
\hline 3 & 0.0 & 76.1 & 18.8 & 5.0 & 0.015 & 0.100 & 0.225 & 15.00 & 2.96 & 3.5 \\
\hline 4 & 0.1 & 69.2 & 23.5 & 7.2 & 0.006 & 0.063 & 0.180 & 30.00 & 3.68 & 4.1 \\
\hline 5 & 1.1 & 70.5 & 19.9 & 8.5 & 0.004 & 0.070 & 0.200 & 57.14 & 7.00 & 4.5 \\
\hline 6 & 0.4 & 58.3 & 18.8 & 22.5 & - & 0.015 & 0.120 & - & - & 13.3 \\
\hline 7 & 0.2 & 67.4 & 16.0 & 16.4 & - & 0.045 & 0.160 & - & - & 9.4 \\
\hline 8 & 1.0 & 74.4 & 17.1 & 7.5 & 0.006 & 0.080 & 0.195 & 35.45 & 5.97 & 6.3 \\
\hline 9 & 0.7 & 72.0 & 18.4 & 8.9 & 0.003 & 0.070 & 0.190 & 63.33 & 8.60 & 7.3 \\
\hline 10 & 0.1 & 69.9 & 12.5 & 17.5 & - & 0.063 & 0.180 & - & - & 8.9 \\
\hline 11 & 0.8 & 55.4 & 26.3 & 17.5 & - & 0.015 & 0.125 & - & - & 8.1 \\
\hline
\end{tabular}

448

449

450 

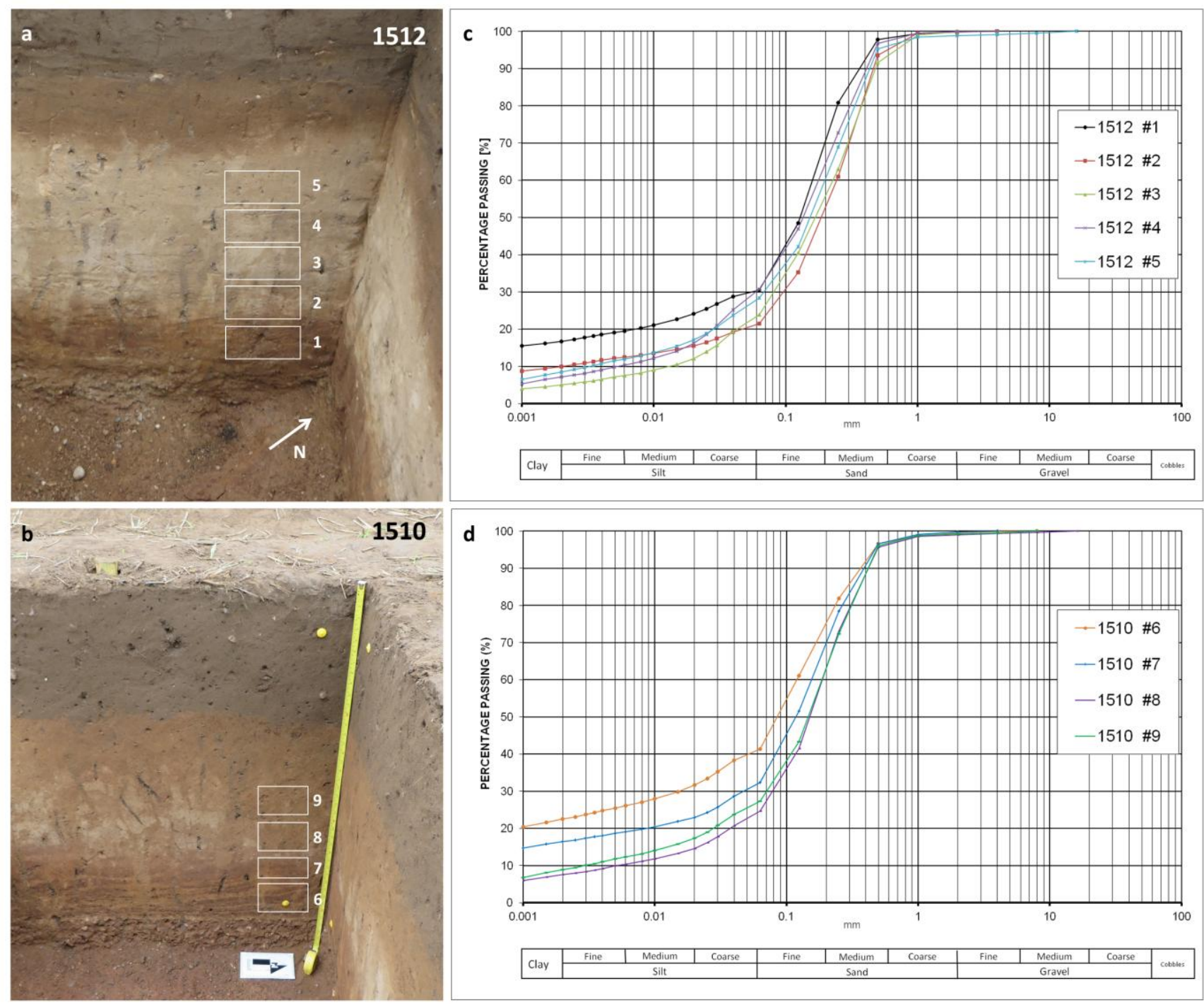

452 Figure 7 - View of the western cross-sections of TP (a) 1512 and (b) 1510, with location and numbering of the 453 samples taken in September 2015; (c-d) respective grain size distribution curves (Photo credits: David Budge 454 and Deodato Tapete). BGS () NERC. All Rights Reserved 2016. 

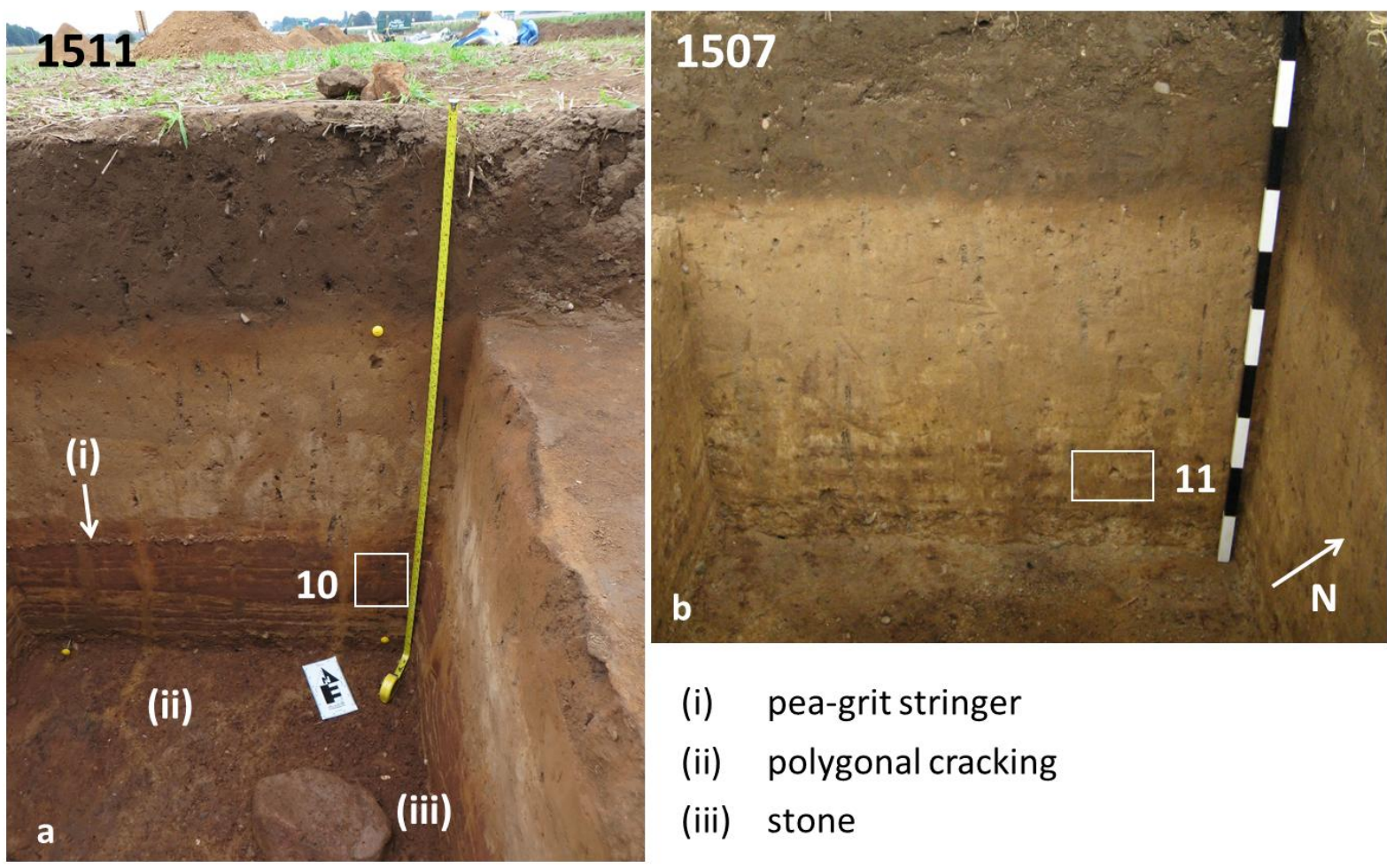
(i) pea-grit stringer
(ii) polygonal cracking
(iii) stone

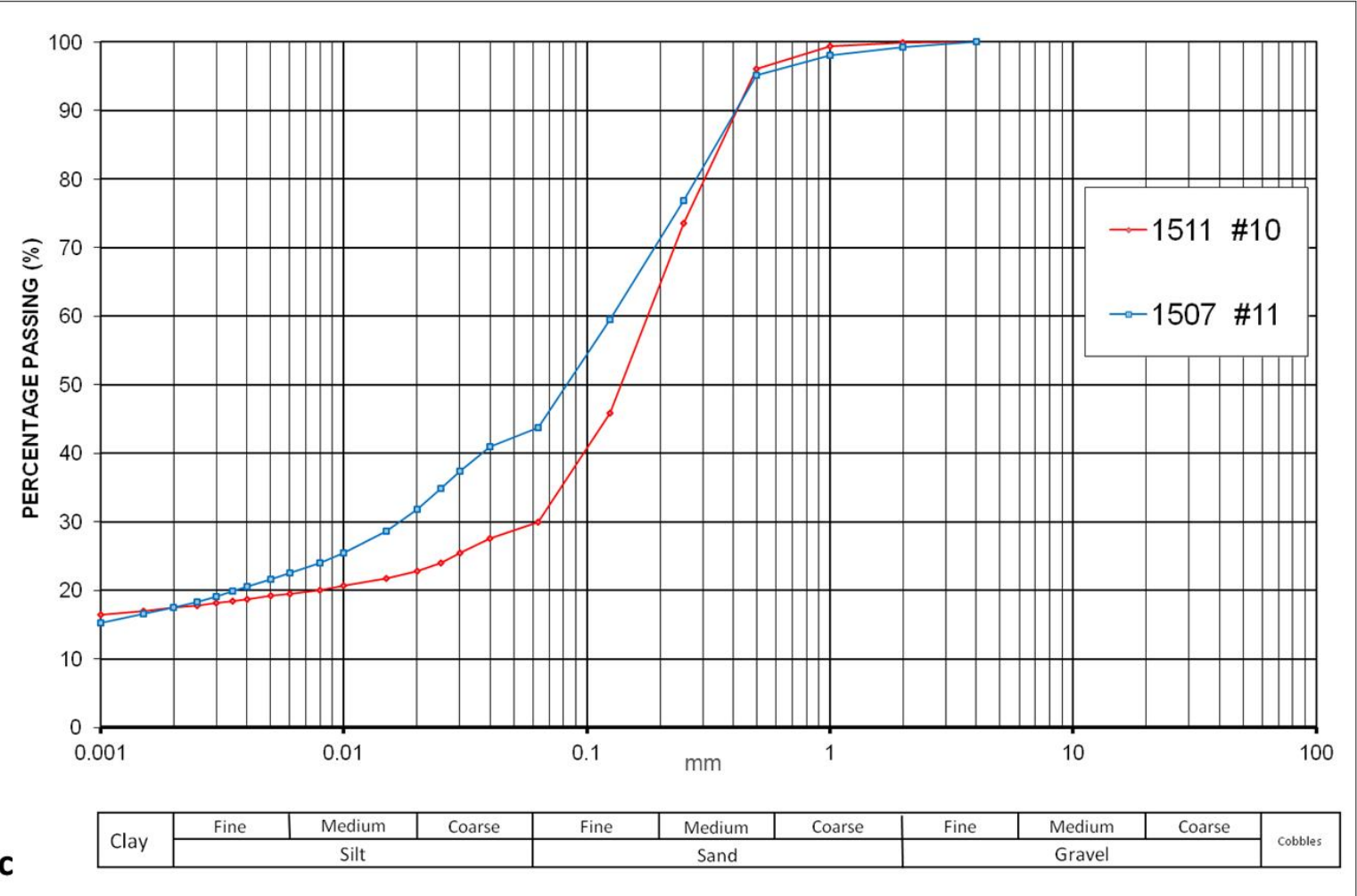

Figure 8 - View of (a) the western cross-section of TP1511 and (b) northern face of TP1507, with location and numbering of the samples taken in September 2015, as well as indication of: (i) pea-grit stringer; (ii) polygonal cracking; (iii) the stone found at the bottom of the pit. (c) Respective grain size distribution curves (Photo credits: Deodato Tapete and Daryl Garton). BGS () NERC. All Rights Reserved 2016. 


\subsection{Geological profiling and feature detection from Terrestrial LiDAR Scanning}

Figure 9 shows the Digital Surface Model (DSM) of Farndon Fields which provides a very high resolution 3D record of the local topography at the time of the archaeological survey. As specified in section 3.4, the DSM was generated by bringing the completed scan data into the 3D point cloud processing software package Maptek I-Site Studio. Vegetation, isolated and un-related points that were random and did not belong to the environment (e.g. due to operators working in the field, animals, objects) were removed. To this purpose, a routine series of filtering tools was applied. The individual scans (see 3D models in Supplementary materials) were then merged into a single feature scan (Figure 9).

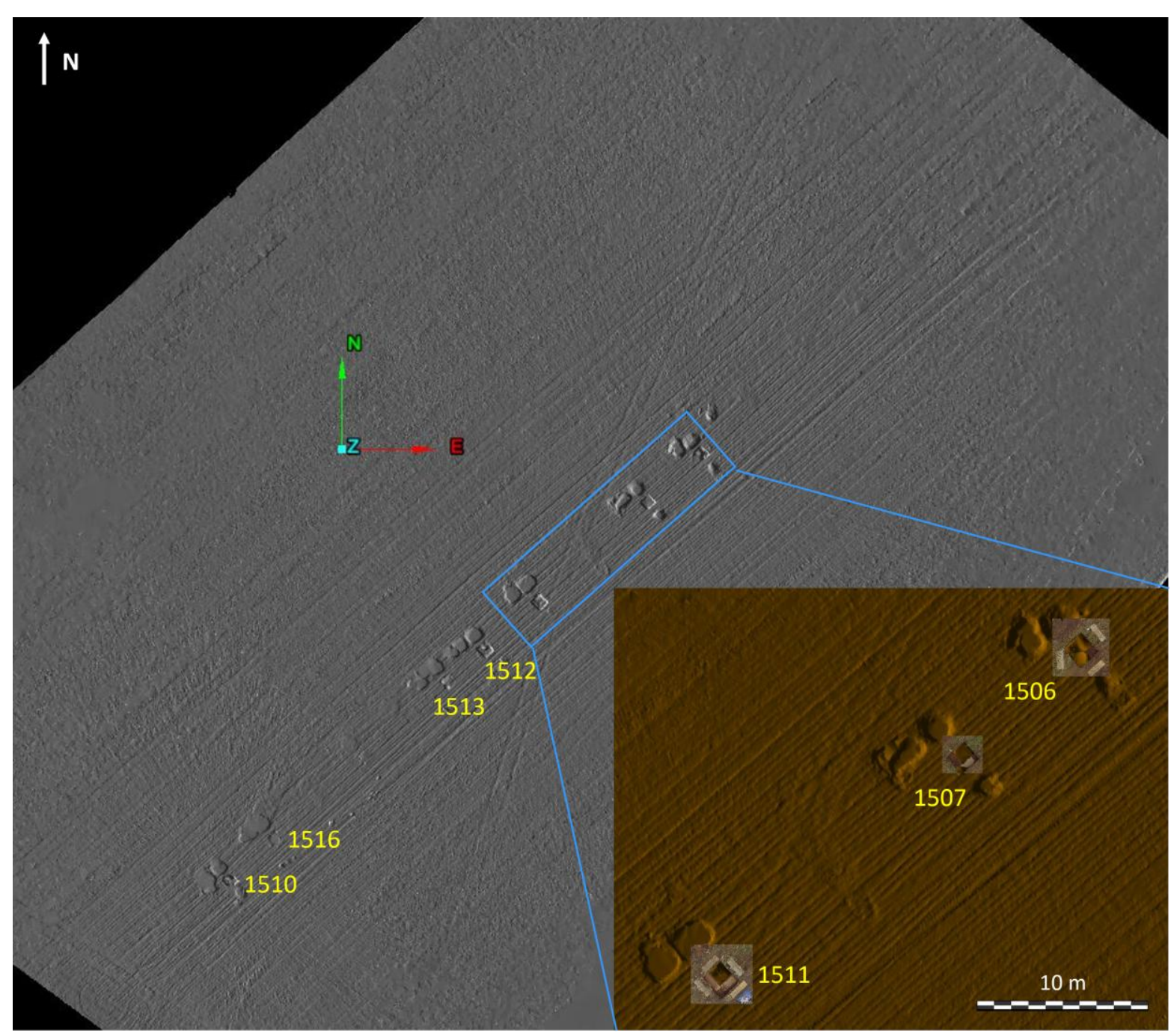

Figure 9 - Farndon Fields Digital Surface Model (DSM) with coloured point clouds of the TP superimposed. BGS (C) NERC. All Rights Reserved 2016. 
From this detailed DSM it is apparent that neither topographic anomalies nor shallow marks suggesting the presence of buried features of archaeological or geological relevance can be observed in the landscape where the TP were dug. Indeed, the maximum elevation variation measured with regard to the scanned TP1506 in the north-east and TP1510 in the south-west along transect A-A' is about 0.6 m. As expected, the highest values coincide with the temporary mounds of excavated soil close to the TP.

The scan points making up the individual TP were highlighted and laid above the DSM. This combined digital product will serve in future to retrieve the exact position of the TP and indicate the presence of ground disturbed by the archaeological excavations. For the purposes of this research, the coloured point clouds acquired and processed for the five TP are used to undertake a holistic analysis of the TP as if they were part of a virtual excavation trench.

Figure 10 shows the Red-Green-Blue (RGB) colour and grey-scale intensity images of TP1510. The $\mathrm{TP}$ is viewed from the south to achieve a full visibility of the northern and north-western cleaned faces and the floor of the pit. The colour contrast in the RGB image and the marked difference of intensity return in the intensity image were used to determine and draw the geological boundaries between the coversands and the overlying ploughsoil and the underlying laminated sediments in all the TP. To connect each TP with the next one, a series of points were marked on the inner faces of the pits at the depths where the same geological boundary between the sediment units was found. Then a surface was interpolated between these points and a series of $0.2 \mathrm{~m}$ contours were created (Figure 11).

The result is a geological profile (Figure 11) which matches the cross-section drawn using traditional techniques (see Figure 6). The advantage is that this geological profile is digital, threedimensional and can be rotated and interrogated. As we move along A-A' transect from the TP1510 to TP1506, the same sediment units are found at deeper depths, thereby resulting in a topographic gradient with total dip angle up to $2^{\circ}$ (Figure 11 ).

$3 \mathrm{D}$ rotation of this virtual geological profile allows an enhanced understanding of the horizontal and vertical distribution of the archaeological and geological deposits within the $\mathrm{x}-\mathrm{y}-\mathrm{z}$ space. Furthermore, 
by means of interpolation, it is also possible to predict the location and depth where the various strata are expected to be found in the gaps between the scanned TP and corroborate the archaeological stratigraphic model of the study transect in Farndon Fields (see also section 4.2).
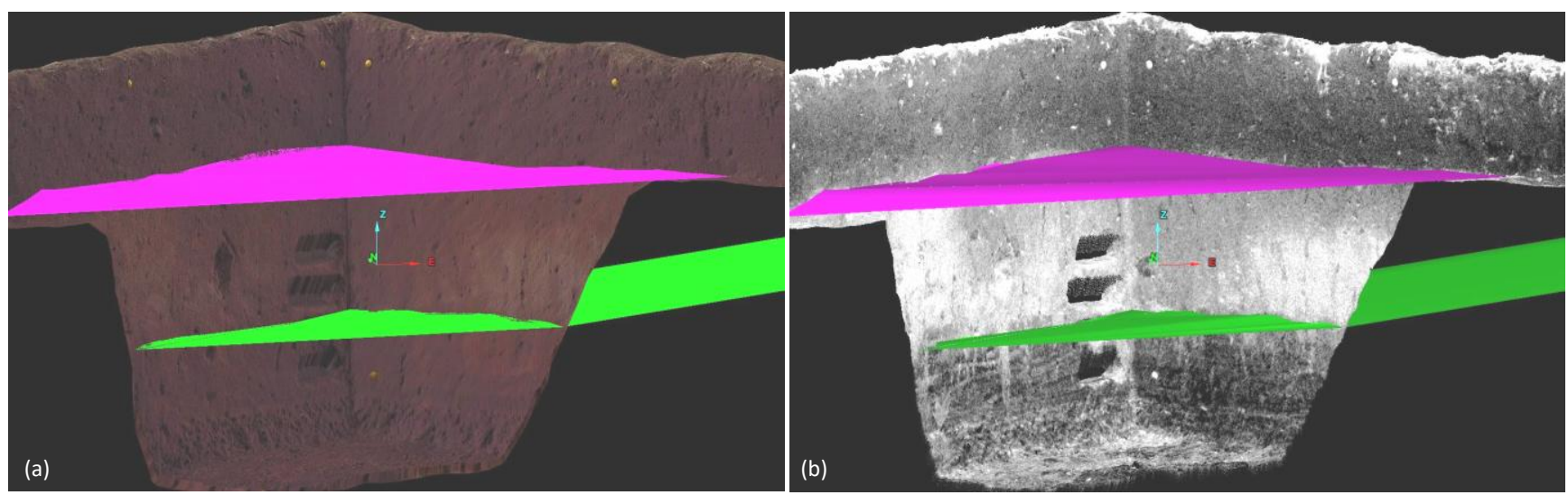

Figure 10 - (a) RGB and (b) grey-scale intensity images of the TP1510 showing the geological boundaries of the coversands (purple) and laminated sediments (green) layers. BGS @ NERC. All Rights Reserved 2016.

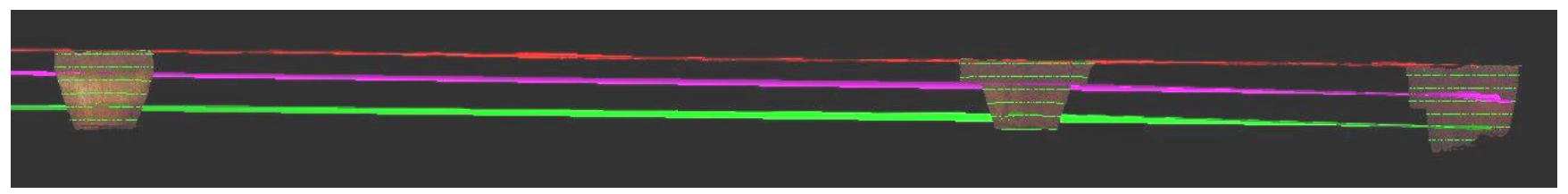

Figure 11 - DSM of the ground surface (red) and interpolated surfaces of the coversands (purple) and laminated sediments (green) layers, for three of the five scanned TP. BGS @ NERC. All Rights Reserved 2016.

The point cloud data of each TP were processed into the software package Cloud Compare and classified by intensity and roughness values. Roughness is here referred to as the distribution of the heights of asperities and protrusions of the inner surfaces of the TP. Asperities and protrusions are defined with regard to a smoother reference surface that has been chosen as the datum.

Figure 12 displays the output of the intensity classification for TP1510, according to a Blue-White-

518 Red colour scheme using intensity thresholds of 1400, 1550 and 1600. Such classification proved to be 519 effective across the TP to pick out the boundaries between the ploughsoil (blue) and the coversands 520 (red), and between the coversands and the laminated sediments (blue), and therefore facilitate an automated calculation of the strata thickness and recognition of depositional and post-depositional 
features. Using this classification technique and colour scheme, we found the evidence of a transition layer between the ploughsoil and the coversands (Figure 13) that was not visibly apparent or well delineated by either the naked eye or on the RGB coloured point cloud. This transition layer follows the upper boundary of the coversands without interruption, but its thickness varies across the TP. In particular, it ranges from $6 \mathrm{~cm}$ as observed in TP1511 (Figure 13) to $16 \mathrm{~cm}$ as measured in TP1512.

With regard to feature detection, the red intensity patterns in Figure 12 clearly mark the presence of infiltrations of the coversand as a pedological overprinting onto the underlying laminated sediments (see black arrows in Figure 12). This is another common feature of the scanned TP that was also recognisable by the naked eye but was seen with improved visibility due to the colour contrast characterising the exposed pit faces. Similar benefit from the use of intensity classification can be appreciated in the capability to delineate the inhomogenities and texture within the sediment units. For instance, it is possible to differentiate the laminations within the laminated sediments themselves (Figure 13), since the bands have average intensity of 1592 against 1478 measured in the surrounding matrix.

The intensity values are also extremely useful for looking at specific geological features, such as convolutions associated with the cryoturbation structure recognised by the archaeologists at the bottom of TP1506 (feature labelled (c) in Figure 14). Figure 15 demonstrates how the intensity image complements the RGB coloured point cloud in making more evident the morphology and texture of the cryoturbation, using in this case a bespoke Blue-Green-Yellow-Red colour scheme. This technique gives a precise record of the very complex sedimentary architecture developed under periglacial conditions. The morphology, as seen in Figure 15d, would suggest a classification of this structure to Type 5 according to Vandenberghe (2013).

Nonetheless, some features that are clearly visible with the naked eye are not picked up very well by the intensity classification, such as the ice crack feature or the pea-grit stringer in TP1511. In these situations the low intensity difference between neighbouring features acted to the detriment of feature discrimination. However, these features can be seen within the RGB coloured point cloud and, even 
549 be found in the enhancement of the local surface roughness and morphology as a consequence of the

550 process of surface triangulation. Surface roughness is a parameter stored in the point cloud that can be

551 extracted and classified to better delineate geological features. Using the tool available in Cloud

552 Compare to estimate the roughness, for each point the kernel, or centre point, is calculated. The

553 'roughness' value retrieved is equal to the distance between this point and the best fitting plane

554 computed on its nearest neighbours.

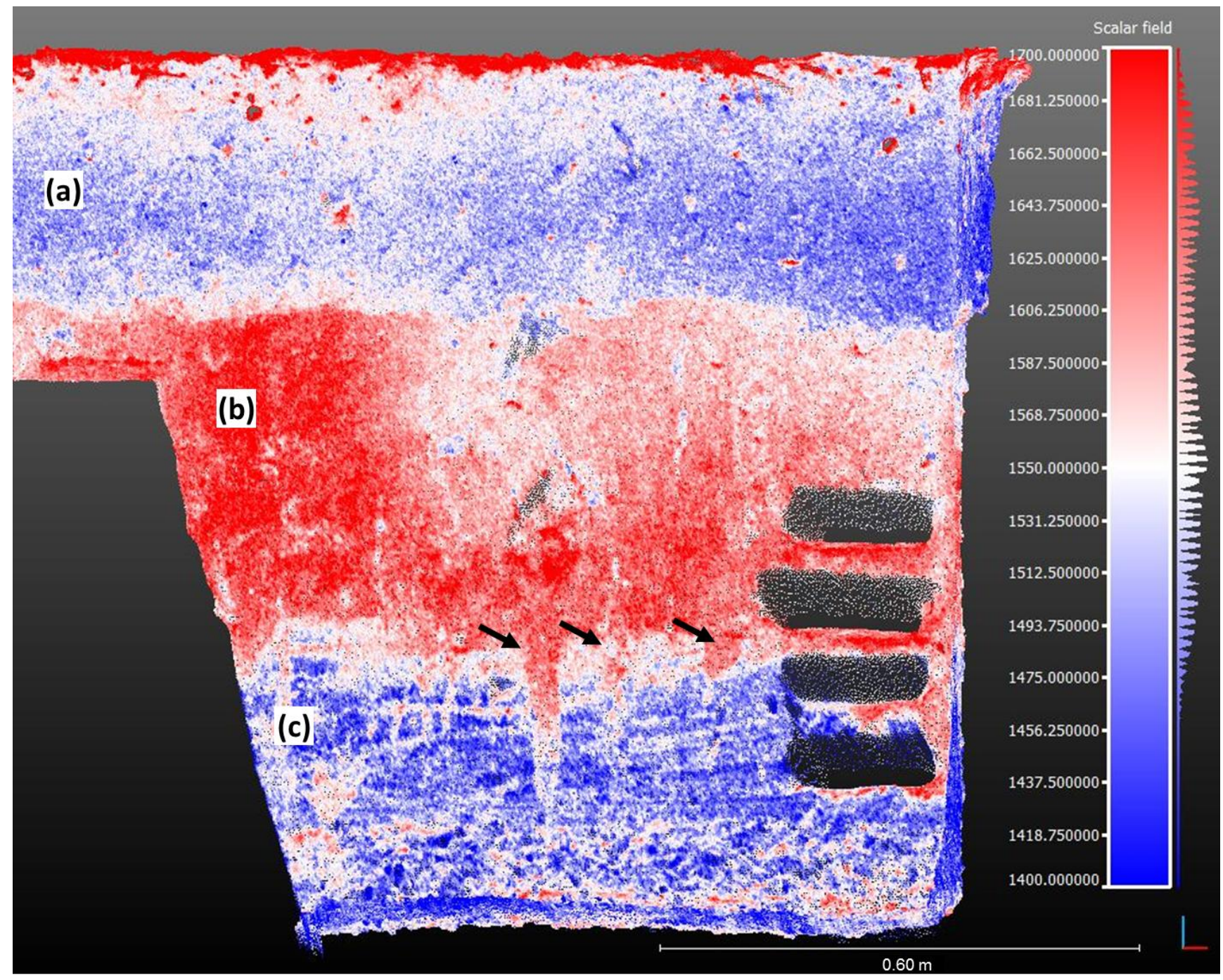

558 Figure 12 - Intensity classification of TP1510 based on Blue-White-Red colour scheme which allows the 559 discrimination, from top, of: (a) ploughsoil; (b) coversand body; (c) laminated sediments. Voids on the right are 560 the cavities left from the sediment sampling. Black arrows mark features due to infiltrations from coversands 561 into the laminated sediments. BGS @ NERC. All Rights Reserved 2016. 


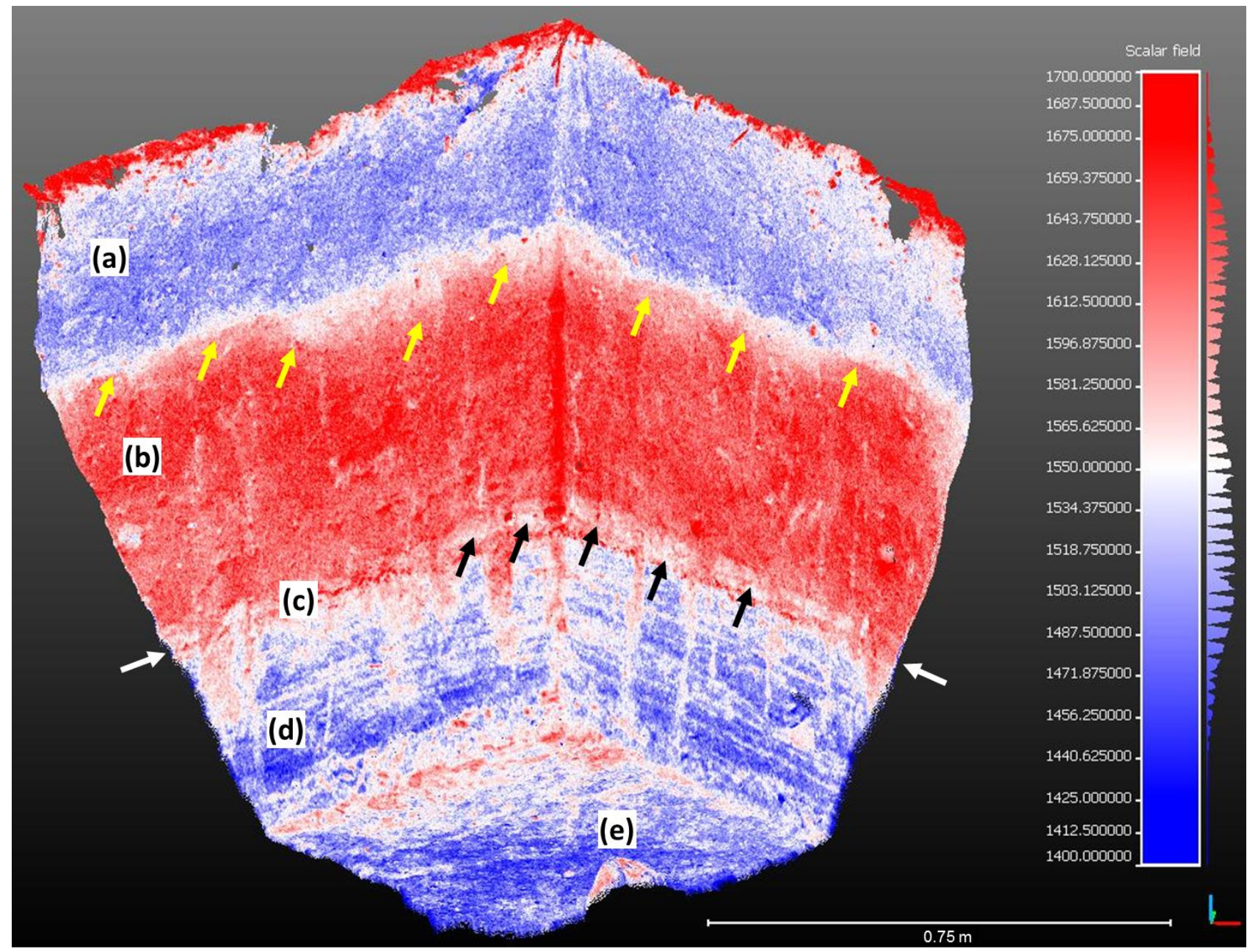

564 Figure 13 - Intensity classification of TP1511 based on Blue-White-Red colour scheme, with indication, from 565 top, of: (a) ploughsoil; (b) coversand body; (c) pea-grit stringer; (d) laminated sediments; (e) stone at the bottom 566 of the pit (compare with Figure 8a). Yellow arrows mark the transition layer between the ploughsoil and the 567 coversands; white arrows point to each end of the pea-grit stringer; black arrows indicate a layer above the pea568 grit stringer that shows distinctive intensity compared to the overlying coversand body. BGS (C) NERC. All 569 Rights Reserved 2016. 


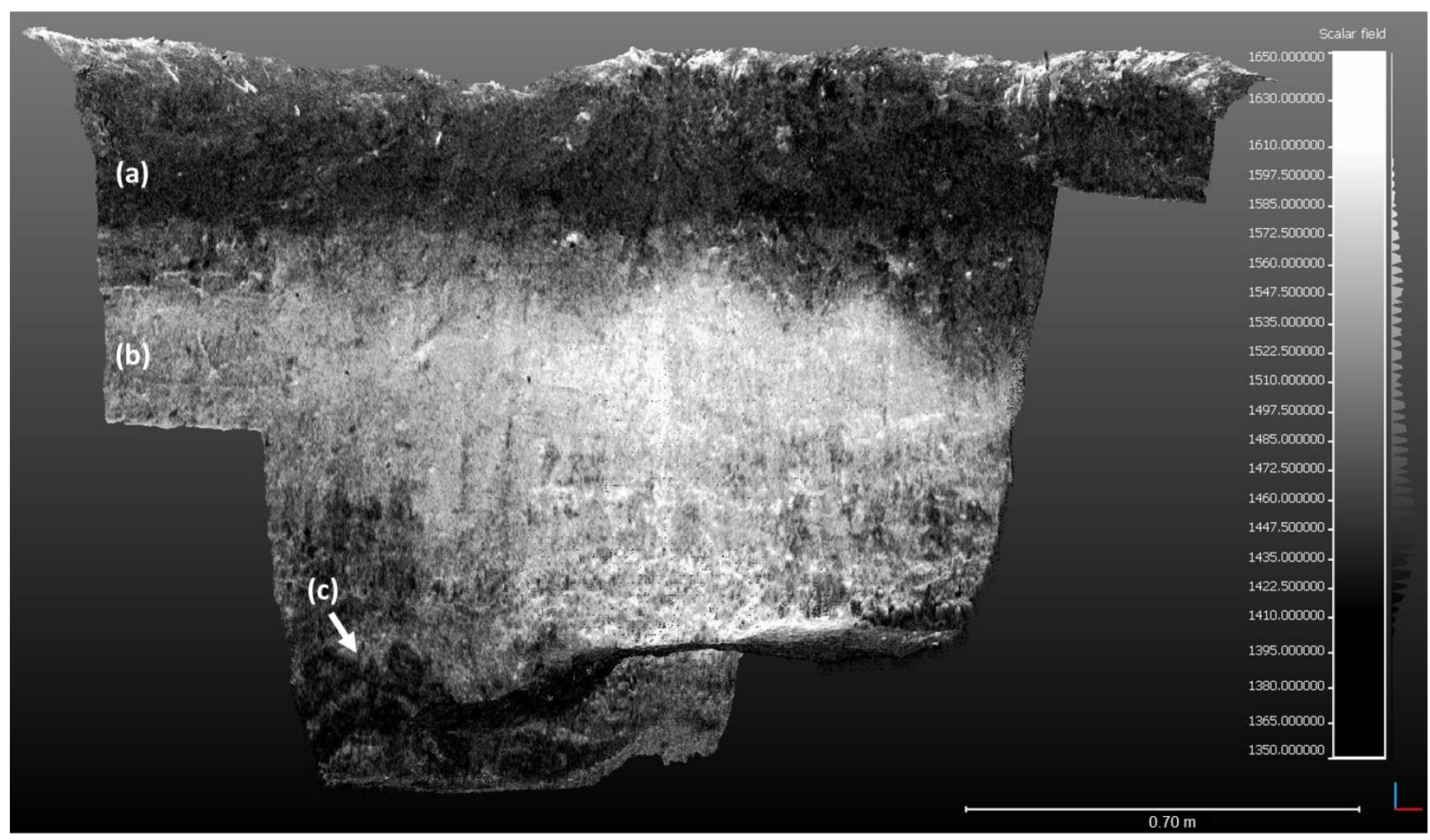

Figure 14 - Cloud intensity of the western and northern faces of TP1506, with indication, from top, of: (a)

573 ploughsoil; (b) coversand body; (c) cryoturbation structure. The intensity returns reveal internal bedding of the 574 coversands that is not visible with the naked eye. BGS @ NERC. All Rights Reserved 2016. 

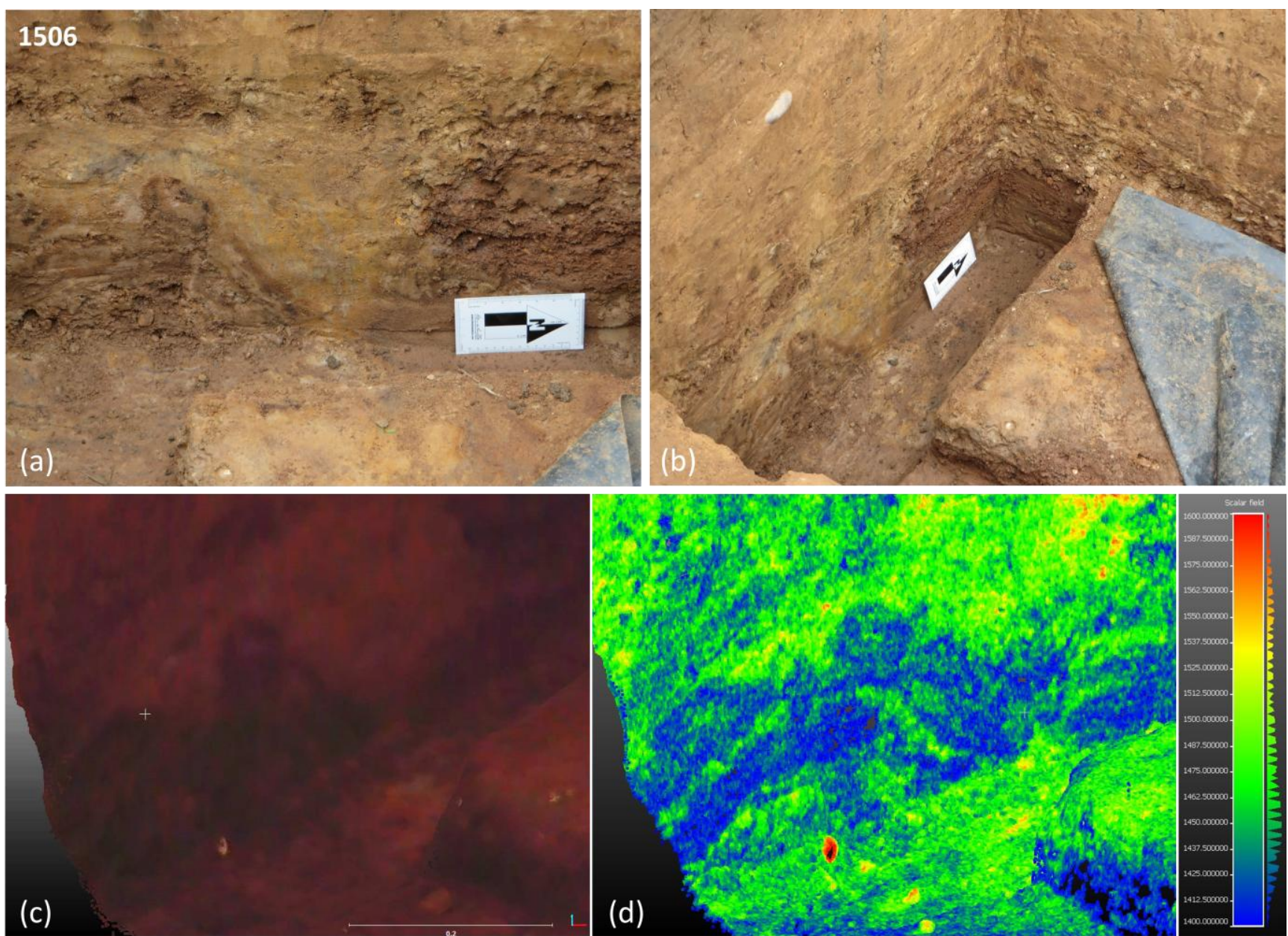

577 Figure 15 - Convolution feature associated with the cryoturbation structure found at the bottom of the 578 stratigraphy exposed in the western face of TP1506 viewed from (a) east and (b) south. (c) RGB and (d) 579 intensity images from the LiDAR scan processing. Scale bar at bottom right of picture (c) measures $0.20 \mathrm{~m}$. 580 (Photo credits (a) and (b): Deodato Tapete). BGS @ NERC. All Rights Reserved 2016. 


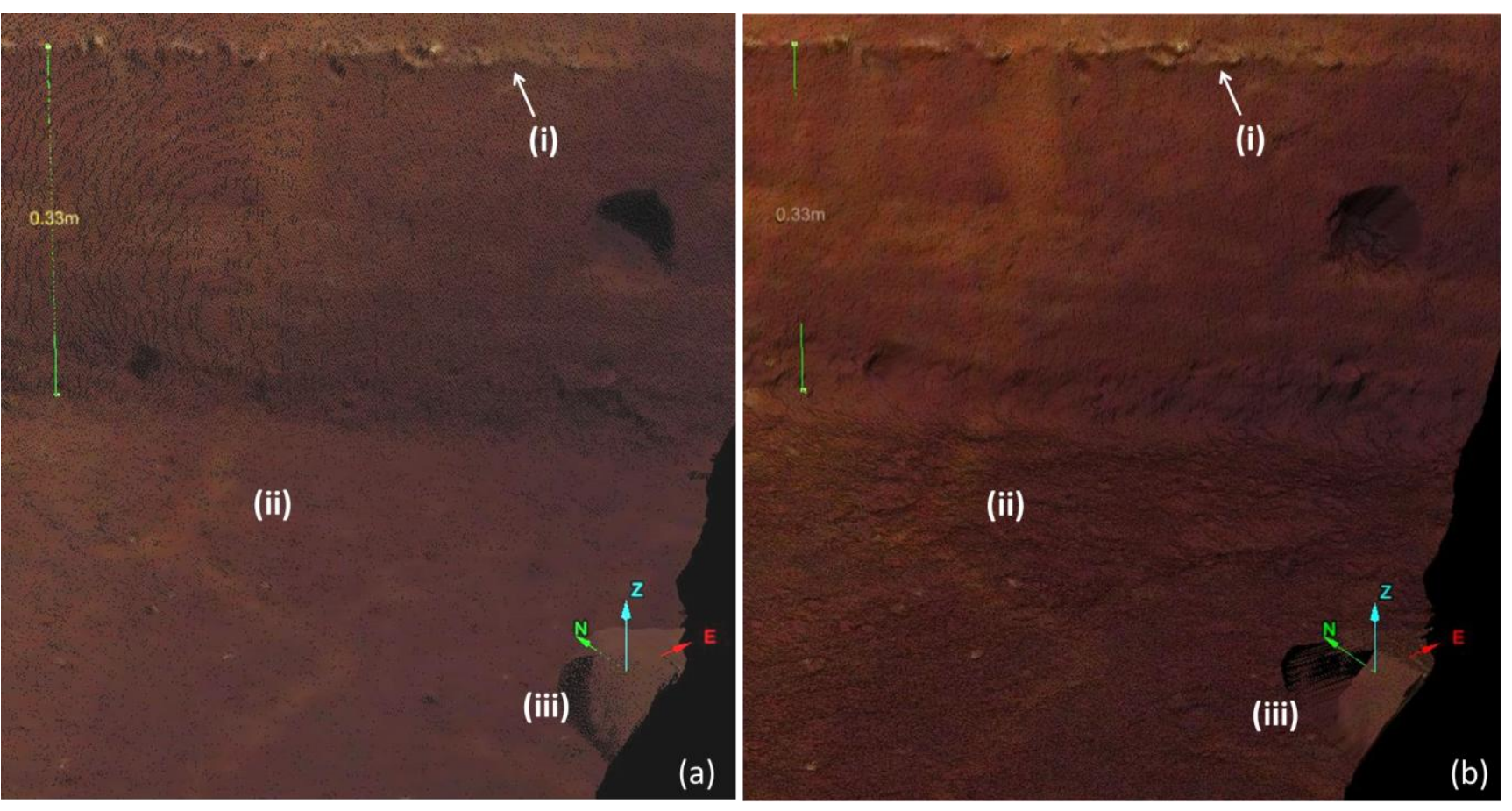

Figure 16 - (a) RGB coloured point cloud and (b) triangulated surface images of the bottom portion of TP1511, with indication of: (i) pea-grit stringer; (ii) ice crack feature; (iii) drop stone (compare with Figure 8a). Note that the circular feature on the right is due to the sediment sampling. BGS @ $)$ NERC. All Rights Reserved 2016.

Figure 17 shows the results for TP1511. The pea-grit stringer close to the upper boundary of the laminated sediments is clearly picked out, thereby providing an effective way to automatically map its distribution and isolate it from the rest of the stratigraphy. The difference of particle size is apparent and this confirms that the pea-grit is quite well-sorted (see also section 4.2), a property that might contribute to unveil the type and energy of the environment when it formed. Other features such as the large drop stone on the pit floor and the sampling locations can also be identified. Nonetheless, limitations to an effective and selective discrimination by surface roughness are in this case due to: (i) the presence of bioturbation/cryoturbation within the coversands that randomly may be classified with similar value as the pea-grit; and (ii) the small gradient along the z-direction (i.e. along the direction orthogonal to the pit face) which may result in some features or parts of them being less clear in the surface roughness map. Of course the corners between the pit faces and the bottom appear rougher due to their geometry, but for the purposes of geological feature investigation they can be neglected and only used as a spatial reference within the $x-y-z$ space. 


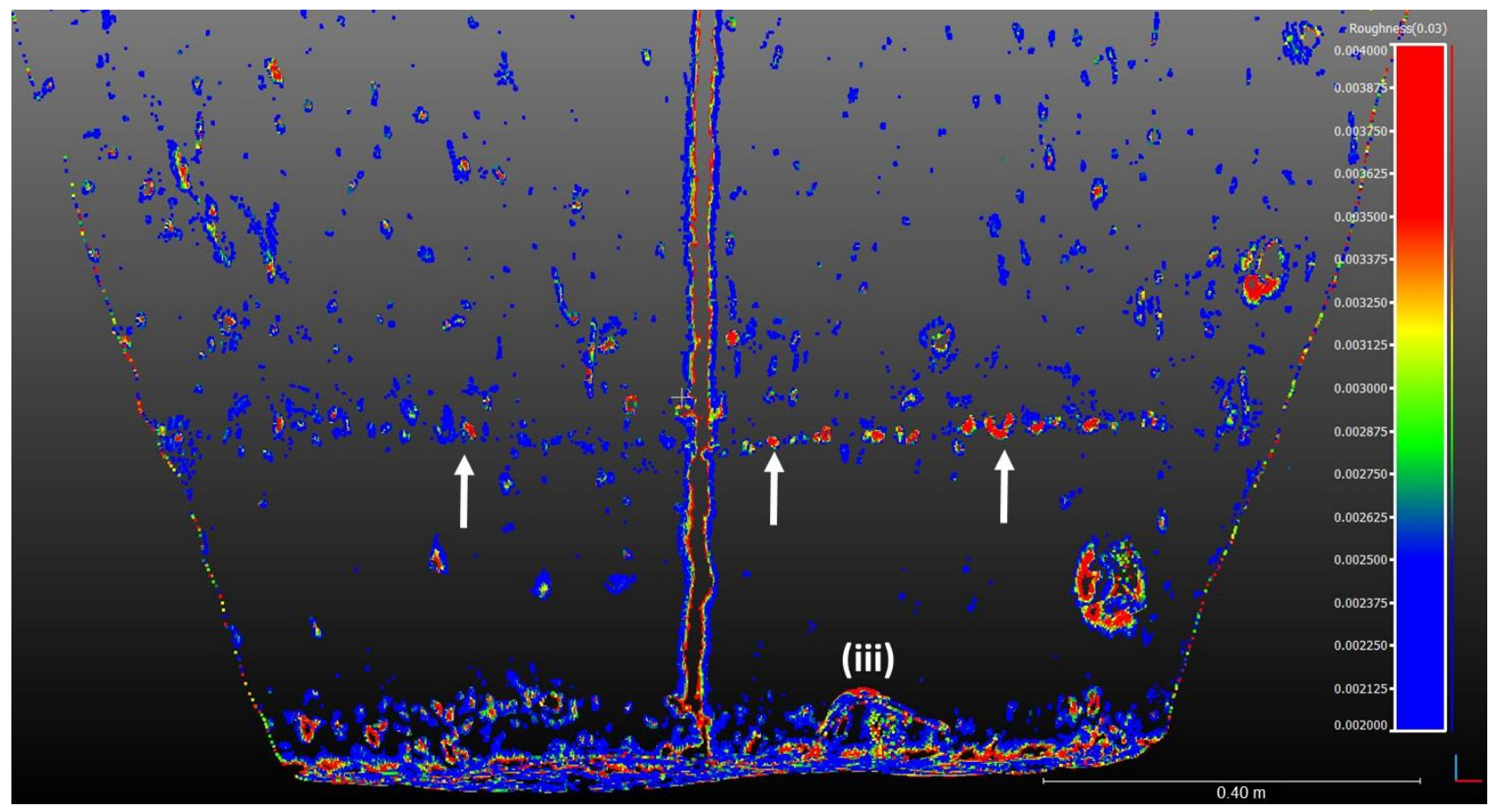

602 Figure 17 - Roughness estimate for TP1511 clearly showing the pea-grit stringer (white arrows). The drop 603 stone on the pit floor is visible (iii; compare with Figure 16). BGS @ NERC. All Rights Reserved 2016.

\section{DISCUSSION}

In the low lying area of the Trent Valley the extent of geology exposed, either as natural outcrops or human-induced exposure (e.g. quarry or excavation trenches), is scant. Such poor exposure of the geology contributes to the research challenges to reconstruct the palaeo-environment in Farndon Fields. Therefore, whilst being the only option available to archaeologists to build on the data obtained from augering, test-pitting was also an opportunity to upgrade the geological mapping through in-situ observation of the structure of the sediment profiles of this area of the River Trent region. This had 612 been recognised by Garton et al. (2015) as a knowledge gap that this research aimed to fill by 613 combining traditional methods (PSA and geological stratigraphic observations) and state-of-the-art 614 LiDAR technologies for regional-scale assessment and local-scale data capture. Airborne LiDAR DTM and aerial photographs were used for modelling of the morphological and topographic setting of an area around Farndon Fields that was chosen for repeated phases of occupation by hunter-gatherers during the Late-Glacial. In this location the longitudinal crest of the 
Holme Pierrepont Sand and Gravel terrace-deposits is interrupted by low-lying land that would support the hypothesis of a floodplain and channel-edge environment where groups of hunters could find a corridor. This information is even more important if we consider that, in addition to the alteration due to farming activities, the site has been recently disturbed by the construction works for the A46 and new development is planned further south. Features of past landscape are already vanishing as multispectral investigation of the area based on false-coloured infrared images from above has demonstrated (Figure 5).

The geological and stratigraphic profile retrieved from the test-pitting clarifies the topographic conformation of the terraces, with a clear SW-NE gradient and a slight step between TP1513 and 1511. Strata of coversands overlie the laminated sediments found at the bottom of the test-pits and their thickness tends to decrease moving towards the NE along transect A-A'. Bioturbation affects the visibility and interpretation of the coversands. This is partially reflected in the PSA results with finer particles within the deeper strata (see section 4.3). Nonetheless, it is worth noting that consistent values and geotechnical parameters are retrieved for the coarser fraction of these sediments at matching depths along the stratigraphic column of the TP.

Whilst it is still matter of conjecture how best to interpret the laminated sediments lying below the coversands (this is outside the scope of this paper), terrestrial LiDAR scans provide new information that could not have been retrieved based on field observations with the naked eye. Intensity classification of the point clouds not only enhances the boundaries between the sediment units, thereby allowing a more precise stratigraphic separation, but also shows discontinuities and variations in the texture and surface roughness within each TP and across the whole test-pitting transect. In particular horizontal laminations and internal bedding of the coversands are observed (Figure 14) and this is completely new evidence that LiDAR technology has brought to light. This could not have been inferred from solely the PSA results. Despite the sampling selectivity, PSA does not appear to be 
Post-processing of the point clouds also proves the added value offered by the LIDAR scans to generate a digital geological profile matching with the traditionally recorded stratigraphic profile, with the functionality of extracting, delineating and measuring features of geological interest, such as the cryoturbation in TP1506 (Figure 15) and the pea-grit layer (Figure 17). It is apparent how this type of digital data can be helpful for desk-based studies and after the closure of temporary excavations, as they remove any ambiguity about the location of the stratigraphic features and samples, and provide a reliable record of the morphology of complex sedimentary structures.

\section{CONCLUSIONS}

The investigation at Farndon Fields demonstrates the benefits of phased investigation (archaeological and geological) as an approach to more cost-effective investigation of archaeological context through strategic sampling of landscape domains.

The analysis of the airborne LiDAR data demonstrates how detailed processing can be used to enhance the understanding of the landscape, e.g. the former distribution of water bodies through the analysis of the form of the low lying ground. The geological data, including the mapped extent of alluvium and the detail recorded on the 1:10,000 field slips form the foundation of this understanding.

At Farndon Fields, the increased resolution of the observations that result from test-pitting, and the new technologies deployed to record and analyse them, have provided an added level of confidence to our ability to discriminate between the laminated sediments, coversands and ploughsoil.

The intensity cloud processing demonstrates that this technique works very well to highlight internal structure in the sediments that would not have been otherwise detected by the naked eye. The roughness index also shows considerable potential for recording the grading of the sediments. The ground based LiDAR results provide a reliable record of the depositional structures (lamination and banding) and grain size that characterise the geological units in the test pits. Although as yet incomplete, the enhanced detail facilitates better interpretation and discrimination of the nature and phasing of the post depositional environmental factors that have affected the strata, such as 
cryoturbation (e.g. ground cracking and water escape features) and bioturbation processes as well as anthropogenic weathering and erosion, including the depth of ploughing and the compaction and consequential increase in soil density that results from ploughing.

It is clear that this type of technology has the potential to support palaeo-environmental research at Farndon and elsewhere as it provides a robust, digital record that can be manipulated and used to capture the detail of both the sediment architecture and the position and timing of any sampling and testing.

Further advance of the research might be to test LiDAR to discriminate between different grading and particle size, but there is the question whether the particle size of these deposits is too fine to be determined by this type of LiDAR, consequently we still rely on traditional methods such as PSA and therefore will continue to need to collect samples. Hand-held LiDAR might provide a technological solution, for example the fact that the pea-grit was clearly detected and extracted as a stratigraphic feature from the LIDAR point cloud is encouraging.

Certainly, the current regional interpretation would benefit from more sampling and more spatial understanding of the heterogeneity of the grading of the sediments, and this would benefit from the techniques that have been demonstrated during the September 2015 phase of test-pitting. Used at the regional scale, with processing being undertaken as an integral part of the investigation as it proceeds, these techniques offer significant potential for planning strategic cost-effective sampling.

This research has confirmed the challenges associated with establishing in-situ subsurface buried terraces, where the modelling of the former landscape will help to predict the location(s) where in-situ contexts for the archaeological finds might be preserved at Farndon Fields.

Investigations of this type offer significant potential for improving the resolution of the geological detail, particularly where archaeology converges with geologically significant sites, e.g. in the case of Farndon Fields, towards the southern edge of the potential former Lake Humber. 


\section{ACKNOWLEDGEMENTS}

695 The research presented in this paper was carried out in the framework of a collaborative project with 696 'Ice Age Journeys', Farndon Archaeological Research Investigations (FARI) and the Palaeolithic 697 Archaeology research group from the University of Oxford. The 'Ice Age Journeys' project was 698 previously supported by Heritage Lottery Funding. The authors from the British Geological Survey 699 (BGS) were funded by BGS Teams 'Urban Geoscience' and 'Shallow Geohazards and Risks' and 700 BGS Engineering Geology science programme. The authors are grateful to: Prof. N. Barton, Dr. S. 701 Colcutt and W.G. Mills from Oxford University and Dr. Colin Baker for their collaboration; Dr. A.S. 702 Howard, S. Price and Dr. S. Chenery from the BGS for the fruitful discussions during this research and 703 all the volunteers involved during the archaeological excavations; and N. Ainiwaer for her help with 704 the terrestrial laser scanning survey during a period of internship with the BGS. A. Myers from the 705 BGS is greatly acknowledged for his invaluable help to create the supplementary materials of this 706 paper. The BGS authors publish with the permission of the Executive Director of BGS, Natural 707 Environment Research Council (NERC).

\section{REFERENCES}

Bailey, G. (2007) Time perspectives, palimpsests and the archaeology of time. Journal of Anthropological Archaeology 26 (2): 198-223. doi:10.1016/j.jaa.2006.08.002

Baker, C., Bateman, M., Bateman, P., Howard, J. (2013) The Aeolian sand record in the Trent Valley. Mercian Geologist 18 (2): 108-118.

Bateman, M.D. (1995) Thermoluminescence dating of the British coversand deposits. Quaternary Science Reviews 14 (7-8): 791-798. doi:10.1016/0277-3791(95)00053-4

Bateman, M.D. (1998) The origin and age of coversand in North Lincolnshire, UK. Permafrost Periglacial Processes 9: 313-325. doi:10.1002/(SICI)1099-1530(199810/12)9:4<313::AIDPPP297>3.0.CO;2-P

Brandon, A., Sumbler, M.G. (1988) An Ipswichian fluvial deposit at Fulbeck, Lincolnshire and the chronology of the Trent terraces. Journal of Quaternary Science 3: 127-133. doi: 10.1002/jqs.3390030204 
Brandon, A., Sumbler, M.G. (1991) The Balderton Sand and Gravel: pre-Ipswichian cold stage fluvial deposits near Lincoln, England. Journal of Quaternary Science 6 (2): 117-138. doi: $10.1002 / j q s .3390060203$

Bridgland, D.R, Howard, A.J., White, M.J., White, T.S. (2014) Quaternary of the Trent. Oxbow Books, Oxford.

Brown, A.G., Carey, C. J., Howard, A. H., Challis, K.C., Cooper, L. (2005) Predictive modelling of multiperiod geoarchaeological resources at a river confluence phase I. Unpublished report for English Heritage, funded through the ALSF scheme. PNUM 3357.

Brown, A.G., Carey, C. J., Howard, A.H., Challis, K.C., Kincey, M. K., Tetlow, E., Cooper, L. (2007) Predictive modelling of multiperiod geoarchaeological resources at a river confluence phase II. Unpublished report for English Heritage, funded through the ALSF scheme. PNUM 3357.

BGS - British Geological Survey (1996) Nottingham sheet E126, solid and drift, 1:50,0000 series.

BGS - British Geological Survey (2016a) DiGMapGB-10. Last accessed on 16 June 2016 at http://www.bgs.ac.uk/products/digitalmaps/DiGMapGB_10.html

BGS - British Geological Survey (2016b) Geology of Britain Viewer. Last accessed on 16 June 2016 at http://mapapps.bgs.ac.uk/geologyofbritain/home.html

BGS - British Geological Survey (2017) The BGS Lexicon of Named Rock Units. http://www.bgs.ac.uk/lexicon/

Burton, D., Wood, L.J. (2010) Lidar Intensity as a Remote Sensor of Rock Properties. Search and Discovery Article \#40618. Last accessed on 12 August 2016 at http://www.searchanddiscovery.com/pdfz/documents/2010/40618burton/ndx_burton.pdf.html

Challis, K. (2005) Airborne LiDAR: a tool for geoarchaeological prospection in Riverine landscapes. In: H. Stoepker (Ed.), Archaeological Heritage Management in Riverine Landscapes, vol. 126 Rapportages Archeologische Monumentenzorg, Amersfoort, pp. 11-24.

Challis, K. (2006) Airborne laser altimetry in alluviated landscapes. Archaeological Prospection 13 (2): 103-127. doi: 10.1002/arp.272

Challis, K., Chris, C., Kincey, M., Howard, A.J. (2011) Assessing the preservation potential of temperate, lowland alluvial sediments using airborne lidar intensity. Journal of Archaeological Science 38 (2): 301-311. doi:10.1016/j.jas.2010.09.006

Clark C.D., Evans, D.J.A., Khatwa, A., Bradwell, T., Jordan, C.J., Marsh, S.H., Mitchell, W.A, Bateman, M.D. (2004) Map and GIS database of glacial landforms and features related to the last British Ice Sheet. Boreas 33: 359-375. doi:10.1111/j.1502-3885.2004.tb01246.x

Doneus, M., Neubauer, W. (2006) Laser scanners for 3D documentation of stratigraphic excavations. In: Recording, Modeling and Visualization of Cultural Heritage, Baltsavias et al. (eds), Taylor \& Francis, pp. 193-203. 
Doneus, M., Neubauer, W. (2005) 3D laser scanners on archaeological excavations. In: CIPA 2005 XX International Symposium, 26 September - 01 October 2005, Torino, Italy. Last accessed on 12 August 2016 at http://cipa.icomos.org/fileadmin/template/doc/TURIN/226.pdf

Edgeworth, M., deB Richter, D., Waters, C., Haff, P., Neal, C., Price, S.J. (2015) Diachronous beginnings of the Anthropocene: The lower bounding surface of anthropogenic deposits. The Anthropocene Review 2 (1): 33-58. doi:10.1177/2053019614565394

English Heritage (2012) Scheduling Selection Guide: Sites of Early Human Activity, p. 5. Last accessed on 12 August 2016 at https://historicengland.org.uk/images-books/publications/dssg-sitesearly-human-activity/

English Heritage (2010) The Light Fantastic. Using airborne lidar in archaeological survey. English Heritage Publishing. Last accessed on 3 March 2017 at https://content.historicengland.org.uk/images-books/publications/light-fantastic/light-fantastic.pdf/

English Heritage (2011) 3D Laser Scanning for Heritage (second edition) Advice and guidance to users on laser scanning in archaeology and architecture. Last accessed on 3 March 2017 at http://content.historicengland.org.uk/images-books/publications/3d-laser-scanningheritage2/3D_Laser_Scanning_final_low-res.pdf/

Fairburn, W.A., Bateman, M.D. (2016) A new multi-stage recession model for Proglacial Lake Humber during the retreat of the last British-Irish Ice Sheet. Boreas 45: 133-151. doi: 10.1111/bor.12140

Fisher, E.C., Akkaynak, D., Harris, J., Herries, A.I.R., Jacobs, Z., Karkanas, P., Marean, C.W., McGrath, J.R. (2015) Technical considerations and methodology for creating high-resolution, color-corrected, and georectified photomosaics of stratigraphic sections at archaeological sites. Journal of Archaeological Science 57: 380-394. doi:10.1016/j.jas.2015.02.022

Folk, R.L. (1974) Petrology of Sedimentary Rocks. Hemphill, Austin, TX, p. 184

Garton, D. (1993) A Late Upper Paleolithic site near Newark, Nottinghamshire. Transactions of the Thoroton Society of Nottinghamshire 97: 144.

Garton, D., Jacobi, R.M. (2009) An extensive Late Upper Palaeolithic flint scatter at Farndon Fields, near Newark, Nottinghamshire. Archaeological Journal 166: 1-37. doi: $10.1080 / 00665983.2009 .11078219$

Garton, D., Baker, C., Banks, V., Barton, N., Budge, D., Collcutt, S., Price, S., Ross, I., Tapete, D., Tyndall, R. (2015) Ice Age Journeys: research by a community archaeology group at Farndon Fields, Nottinghamshire. Transactions of the Thoroton Society of Nottinghamshire 119: 103-140.

Harding, P., Ellis, C., Grant, M.J. (2014) Late Upper Palaeolithic Farndon Fields. In: Cooke, Nicholas and Mudd, Andrew (eds.) A46 Nottinghamshire: The Archaeology of the Newark to Widmerpool Improvement Scheme, 2009. Salisbury, GB, Wessex Archaeology, pp. 12-70. 
Highways Agency (2012) Following the Fosse Way through Nottinghamshire. Archaeology and the A46. Cotswold Wessex Archaeology, 16 pp. Last accessed on 12 August 2016 at http://assets.highways.gov.uk/roads/road-projects/a46-newark-to-widmerpoolimprovement/m120008_Following the Fosse_Way_through_Nottinghamshire_Archaeology_and $\mathrm{t}$ he_A46_proof_low.pdf

Howard, A.S., Warrington, G., Carney, J.N., Ambrose, K., Young, S.R., Pharaoh, T.C., Cheney, C.S. (2009) Geology of the Nottingham District. Memoir of the British Geological Survey, Sheet 126 (England and Wales).

Howard, A.J., Bridgland, D.R., Knight, D., McNabb, J., Rose, J., Schreve, D.C., Westaway, R., White, M.J., White, T.S. (2007) The British Pleistocene fluvial archive: East Midlands drainage evolution and human occupation in the context of the British and NW European record. Quaternary Science Reviews 26 (22-24): 2724-2737. doi:10.1016/j.quascirev.2007.06.029

Howard, A.J., Brown, A.G., Carey, C.J., Challis, K., Cooper, L.P., Kincey, M., Toms, P. (2008) Archaeological resource modelling in temperate river valleys: a case study from the Trent Valley, UK. Antiquity, 82(318): 1040-1054. doi: 10.1017/S0003598X00097763

Howard, A.J., Carney, J.N., Greenwood, M.T., Keen, D.H., Mighall, T., O'Brien, C., Tetlow, E. (2011) The Holme Pierrepont sand and gravel and the timing of Middle and Late Devensian floodplain aggradation in the English Midlands. Proceedings of the Geologists' Association 122(3): 419-431. doi:10.1016/j.pgeola.2011.03.009

Jacobi, R.M., Higham, T.F.G. (2009). The early Lateglacial re-colonization of Britain: new radiocarbon evidence from Gough's Cave, southwest England. Quaternary Science Reviews 28: 1895-1913. doi:10.1016/j.quascirev.2009.03.006

Kinsley, G., Knight, D. (1992) Archaeology of the Fosse Way. Vol. 2: Newark to Widmerpool. Trent \& Peak Archaeological Trust.

Knight, D. (2004) A46 Newark to Widmerpool Improvement: archaeological research framework. Report for Highways Agency, 22.11.04, Trent \& Peak Archaeological Unit, p. 8.

Knight, D., Howard, A.J. (2004) Trent Valley Landscapes. The Archaeology of 500000 years of change. Trent Valley Geoarchaeology. Heritage Marketing and Publications Limited, 202 pp.

Knight, D., Vyner, B., Allen, C. (2012) East Midlands Heritage. An Updated Research Agenda and Strategy for the Historic Environment of the East Midlands. Nottingham Archaeological Monographs 6, Buxton Press, Buxton, Derbyshire, p. 29.

Koster, E.A. (1988) Ancient and modern cold-climate aeolian sand deposition: a review. Journal of Quaternary Science 3 (1): 69-83. doi: 10.1002/jqs.3390030109

Krooks, A., Kaasalainen, S., Hakala, T., Nevalainen, O. (2013) Correction of intensity incidence angle effect in terrestrial laser scanning. In: ISPRS Annals of the Photogrammetry, Remote Sensing and 
Spatial Information Sciences, Volume II-5/W2, 2013 ISPRS Workshop Laser Scanning 2013, 11 13 November 2013, Antalya, Turkey, pp. 145-150. Accessed at http://www.isprs-ann-photogrammremote-sens-spatial-inf-sci.net/II-5-W2/145/2013/isprsannals-II-5-W2-145-2013.pdf

Lerma, J.L., Navarro, S., Seguí, A.E., Cabrelles, M. (2014) Range-based versus automated markerless image-based techniques for rock art documentation. Photogrammetric Record 29 (145): 30-48. doi: 10.1111/phor.12054

Malone, S.J. (2012) Lincolnshire Fenland Lidar. Heritage Trust. Working Paper 1. Lincolnshire/ Archaeology Project Services. British Archaeology 127: 48-49.

Pfeifer, N., Dorninger, P., Haring, A., Fan, H. (2007) Investigating terrestrial laser scanning intensity data: quality and functional relations, pp. 328-337 Last accessed on 12 August 2016 at http://publik.tuwien.ac.at/files/pub-geo_1932.pdf

Price, D., Rogers, P.J. (1978) The sand and gravel resources of the country west of Newark on Trent, Nottinghamshire. Description of 1: 25000 resource sheet SK 75. Mineral Assessment Report Institute Geological Sciences, 31, 70 pp.

Rapp, G.R., Hill, C.L. (2006). Geoarchaeology: The Earth-Science Approach to Archaeological Interpretation. New Haven; London: Yale University Press.

Sanger, M.C. (2005) Determining depositional events within shell deposits using computer vision and photogrammetry. Journal of Archaeological Science 53: 482-491. doi:10.1016/j.jas.2014.10.026

Schiffer, M.B. (1987) Formation processes of the archaeological record. Albuquerque, NM: University of New Mexico Press.

TPAU - Trent and Peak Archaeology Unit (2004) Trent and Peak Archaeological Unit (2004) Farndon Fields, Nottighamshire: Assessment of the Evidence for the Late Upper Palaeolithic Activity and Its Importance. Unpublished client report ref FNW 2.

Vandenberghe, J. (2013) Cryoturbation Structures. In: Encyclopedia of Quaternary Science, vol. 3, pp. 430-435, revision of the previous edition article Vandenberghe, J. (2007) Periglacial landforms. Cryoturbation Structures. In: Encyclopedia of Quaternary Science, S.A. Elias (ed), Elsevier, Oxford, 2007, pp. 2147-2153. Last accessed on 12 August 2016 at https://www.researchgate.net/publication/282677513_Cryoturbation_structures

Wessex Archaeology (1995) Farndon Fields, Newark on Trent, Nottinghamshire. Archaeological Evaluation. Fieldwalking, Auger Survey and test pitting.

Wessex Archaeology (2006) Newark to Widmerpool Improvements Archaeological Works at Farndon Fields (A46 FAR05) Fieldwork Report. 29 pp. 